NBER WORKING PAPER SERIES

\title{
TRADE REFORMS AND WAGE INEQUALITY IN COLOMBIA
}

\author{
Orazio Attanasio \\ Pinelopi K. Goldberg \\ Nina Pavcnik \\ Working Paper 9830 \\ http://www.nber.org/papers/w9830 \\ NATIONAL BUREAU OF ECONOMIC RESEARCH \\ 1050 Massachusetts Avenue \\ Cambridge, MA 02138 \\ July 2003
}

\begin{abstract}
We wish to thank Hector Mejia at DANE and Andreas Blom at the World Bank for providing us with the data. We are also grateful to Cristina Gamboa, Adriana Kugler, Jairo Nuñez Mendez, and Ximena Pena for answering our numerous questions about the data and the Colombian reforms, and to Eric Edmonds, Ravi Kanbur, and two anonymous referees for useful comments and suggestions. Goldberg and Pavcnik gratefully acknowledge financial support from the National Science Foundation Grant SES \#0213459. Goldberg acknowledges financial support from the Alfred P. Sloan Foundation through a Faculty Research Fellowship. Pavcnik acknowledges the support from the Rockefeller Social Science Faculty Grant. The views expressed herein are those of the authors and not necessarily those of the National Bureau of Economic Research
\end{abstract}

(C2003 by Orazio Attanasio, Pinelopi Goldberg, and Nina Pavcnik. All rights reserved. Short sections of text not to exceed two paragraphs, may be quoted without explicit permission provided that full credit including (C notice, is given to the source. 
Trade Reforms and Wage Inequality in Colombia

Orazio Attanasio, Pinelopi K. Goldberg, and Nina Pavcnik

NBER Working Paper No. 9830

July 2003

JEL No. F10, F13, J31

\section{$\underline{\text { ABSTRACT }}$}

We investigate the effects of the drastic tariff reductions of the 1980s and 1990s in Colombia on the wage distribution. We identify three main channels through which the wage distribution was affected: increasing returns to college education, changes in industry wages that hurt sectors with initially lower wages and a higher fraction of unskilled workers, and shifts of the labor force towards the informal sector that typically pays lower wages and offers no benefits. Our results suggest that trade policy played a role in each of the above cases. The increase in the skill premium was primarily driven by skilled-biased technological change; however, our evidence suggests, that this change may have been in part motivated by the tariff reductions and the increased foreign competition to which the trade reform exposed domestic producers. With respect to industry wages, we find that wage premiums decreased by more in sectors that experienced larger tariff cuts. Finally, we find some evidence that the increase in the size of the informal sector is related to increased foreign competition - sectors with larger tariff cuts and more trade exposure, as measured by the size their imports, experience a greater increase in informality, though this effect is concentrated in the years prior to the labor market reform. Nevertheless, increasing returns to education, and changes in industry premiums and informality alone cannot fully explain the increase in wage inequality we observe over this period. This suggests that overall the effect of the trade reforms on the wage distribution may have been small.

$\begin{array}{ll}\text { Orazio Attanasio } & \text { Pinelopi K. Goldberg } \\ \text { Department of Economics } & \text { Department of Economics } \\ \text { University College London } & \text { Yale University } \\ \text { Gower Street } & \text { 37 Hillhouse Avenue } \\ \text { London WC1E 6BT } & \text { P.O. Box 208264 } \\ \text { United Kingdom } & \text { New Haven, CT 06520-8264 } \\ \text { and NBER } & \text { and NBER } \\ \text { o.attanasio@ucl.ac.uk } & \text { penny.goldberg@yale.edu }\end{array}$

Nina Pavcnik

Department of Economics Dartmouth College 6106 Rockefeller Center Hanover, NH 03755 and NBER and CEPR nina.pavcnik@dartmouth.edu 


\section{Introduction}

Starting in 1985, Colombia experienced gradual trade liberalization that culminated in the drastic tariff reductions of 1990-91. The trade reform was accompanied by major modifications of the labor regime in order to reduce labor rigidities, and reforms in the financial sector for the purpose of enhancing resource mobility. The purpose of the trade reforms was to expose domestic producers to international competition, increase efficiency, accelerate growth and reduce at the same time the prices faced by consumers. While the empirical evidence to date suggests that the reforms have indeed been associated with increased efficiency and growth, there have also been concerns that trade liberalization may have contributed to an increase in income inequality. These concerns are partly rooted in the experience of Mexico, which experienced a substantial rise in the skill premium and overall income inequality following the trade reform of the mid-1980's. While a causal link between the Mexican trade liberalization and inequality was never established beyond dispute, the chronological coincidence of the increase in wage dispersion with the trade reforms was nevertheless a disappointment to those who hoped that globalization would benefit the poor in developing countries.

The purpose of our work is to provide an empirical investigation of the relationship between wage inequality and trade liberalization in Colombia using detailed micro level data from 1984-1998. In particular, we exploit detailed data on workers' earnings, characteristics and industry affiliation from the Colombian National Household Survey (NHS) and link this information to industry-level tariff changes and trade exposure. The main advantage of focusing on Colombia is that Colombia, like other developing countries, had not participated in the tariff reducing rounds of the GATT, so that tariff levels were high prior to the reforms. Trade reform consisted primarily of drastic tariff reductions. ${ }^{1}$ Tariffs are both well measured and unlike NTBs comparable across time. In addition, the period 1985-1994 includes multiple tariff reduction episodes that affected not only the average tariff, but also the structure of protection across industries. Changes in the structure of protection reflected the country's commitment to economy-wide reforms that reduced tariff dispersion, and set tariff rates to levels comparable to those in developed countries. These rates were negotiated with the WTO. Policy makers had accordingly less room to cater to special lobby interests; from an individual industry's perspective, the final tariff rates were exogenously predetermined.

\footnotetext{
${ }^{1}$ Trade liberalization in Colombia also reduced nontariff barriers to trade (NTBs).
} 
We conduct our analysis in several steps. We start by documenting the basic facts concerning wage inequality in Colombia over 1984-1998. We find that while inequality gradually increased over this period, the increase was by no means as pronounced as in Mexico. Next, we decompose inequality into a component that reflects changes in the returns to education, and a component that captures inequality within educational groups. While, consistent with the experience in other Latin American economies, the return to college education increases over our sample period, this increase is modest compared to Mexico. At the same time, we document an increase in inequality within educational groups, suggesting that the skill premium alone cannot explain the rise in wage inequality.

Next, we use regression analysis to identify, for each year, the effects that several factors, such as industry affiliation, education, and various individual and job characteristics (e.g., informality) have on individual wages. Having many years of data, we can examine how the coefficients on the above variables change over time. We show that individuals with the same characteristics and skills receive different compensation depending on the industry sector in which they work, the occupation they have, and whether their job is formal or informal. Moreover, we show that industry premiums, and returns to education, occupation, and informality change over time.

This descriptive analysis motivates our focus on the skill premium, industry premiums, occupations, and informality in the rest of the paper. For each of the above factors, we discuss through which channels trade reform is expected to have had an effect, and then examine whether our expectations are confirmed by relating the observed changes to changes in tariffs. As our sample is representative of the urban workforce, we also analyze how its composition changes in terms of skills, and how these changes differ across sectors. We again relate these changes to the changes in tariffs and interpret our results in light of different theoretical models.

Our main findings can be summarized as follows: First, we find that changes in skill premiums are roughly the same across industries and cannot be related to changes in tariffs across sectors. At the same time, we find no evidence of labor re-allocation across sectors. We argue that this piece of evidence is inconsistent with the hypothesis that the skill premium increase was driven by the adjustment mechanism indicated by the workhorse model of international trade, the Heckscher-Ohlin model. This mechanism would suggest labor reallocation from sectors that experienced larger tariff reductions (and hence a reduction in the 
price of their output) towards sectors that were affected less by trade liberalization. However, the industry employment shares remain stable over our sample period, and the small changes we observe cannot be related to trade policy.

Second, we find that the proportion of skilled workers rose in every industry, consistent with the hypothesis of skill-biased technological change. At the same time, we find that skillbiased technological change was larger in sectors that experienced larger tariff reductions, suggesting that skill-biased technological change itself was partly an endogenous response to increased foreign competition.

Third, we find that the trade reforms impacted industry wage premiums. Wage premiums represent the portion of industry wages that cannot be explained through worker or firm characteristics. They can be interpreted as either industry rents, or returns to industry specific skills that are not transferable in the short run, and are particularly relevant in the presence of imperfect competition, and/or in cases in which labor mobility is constrained. We find that sectors that were associated with proportionately larger decreases in protection experienced a decrease in their wage premiums relative to the economy-wide average. This suggests an additional channel through which the wage distribution in Colombia was affected. Our empirical evidence suggests that trade liberalization was concentrated in labor-intensive sectors employing a high percentage of low-skill labor. If these sectors experienced a decrease in their wage premiums, then less-skilled workers were "hit" by the reforms twice: First they saw the average return to their skill decrease, and second they saw the industry specific return in the sectors they were employed go down. Moreover, the sectors that had the highest protection before the reform were typically characterized by the smallest wage premiums. Our finding of a trade reform induced reduction in wage premiums, therefore, explains, at least in part, the observed increase in inequality.

Finally, we find some evidence that the trade reforms contributed to an increase in the size of the informal sector. Critics of trade liberalization have expressed the fear that intensified foreign competition may induce large and medium-sized firms to cut worker benefits in order to reduce costs. To this end, such firms may replace permanent by temporary workers, or outsource activities to small, informal firms, including home-based and self-employed microenterpreneurs. This view finds some support in our results, which indicate that sectors that experienced larger tariff reductions and an increase in imports saw a rise in informal employment, though this effect 
is concentrated in the years prior to the labor market reform. Because the informal sector does not provide benefits and is believed to offer lower job quality, this trend would contribute to an increase in inequality.

Overall, we conclude that the trade reforms in Colombia did affect the wage distribution (via their impact on skill-biased technological change, industry wage premiums, and informality), but the overall effect was modest compared to other countries, especially Mexico.

\section{Data}

\subsection{Data on Trade Reforms}

Colombia's trade policy underwent significant changes during the past three decades. Although Colombia considerably liberalized its trading environment during the late 1970s, the government increased protection during the early 1980s in an attempt to combat the impact of the exchange rate appreciation and intensified foreign competition. ${ }^{2}$ As a result, the average tariff level increased to 27 percent in 1984. The level of protection varied widely across industries. Manufacturing industries enjoyed especially high levels of protection with an average tariff of 50 percent. Imports from the two most protected sectors, textiles and apparel, and wood and wood product manufacturing, faced tariffs of over 90 percent and 60 percent respectively. This suggests that Colombia protected relatively unskilled, labor-intensive sectors, which conforms to findings by Hanson and Harrison (1999) for Mexico. From 1985 to 1994, Colombia gradually liberalized its trading regime by reducing the tariff levels and virtually eliminating the non-tariff barriers to trade.

Table 1a provides the average tariff across all industries, and across manufacturing from 1984 to 1998 , the period of our study. ${ }^{3}$ The average tariff declined from 27 to about 10 percent from 1984 to 1998 . The average tariff level in manufacturing dropped from 50 to 13 percent during the same period. The bottom part of table 1a summarizes the average NTBs in 1986, 1988, and 1992. ${ }^{4}$ In 1986, the average coverage ratio was 72.2 percent. As is the case with tariffs, NTB protection varies widely across industries, with textiles and apparel industry and the

\footnotetext{
${ }^{2}$ High world prices of coffee, significant foreign borrowing by Colombia, and illegal exports all contributed to the large appreciation of the peso during the late 1970s and early 1980s (Roberts and Tybout (1997)).

${ }^{3}$ The source of tariff information is the Colombian National Planning Department (DNP). Overall, they are available for 21 2-digit ISIC industries. See Goldberg and Pavcnik (2003a) for details.

${ }^{4}$ The source of NTB information is the United Nation's publication Directory of Import Regimes. NTBs are measured as coverage ratios. They are available for 17 2-digit ISIC sectors.
} 
manufacturing of wood and wood products enjoying the highest level of protection. Between 1990 and 1992, the average NTB dropped to 1.1 percent.

What is remarkable about the Colombian trade reforms is that they did not just reduce the average level of tariffs and NTBs, they more importantly changed the structure of protection. As a result, the correlation between the tariffs before and after the reforms is very low (for example, the year to year correlation between tariffs in 1984, the year preceding the reforms, and 1992, the year following the major reforms is .54). The same is true for NTBs; the correlation of NTBs between 1986 and 1992 is not significantly different from zero (.10 with a p-value of .69). In our empirical work we exploit this cross-sectional variation in protection changes to identify the differential impact of the reforms on earnings in each sector, and examine whether these changes contributed to the increase in inequality.

\subsection{National Household Survey}

We relate the trade policy measures to household survey data from the $1984,1986,1988$, 1990, 1992, 1994, 1996, and 1998 June waves of the Colombian National Household Survey (NHS) administered and provided by the Colombian National Statistical Agency (DANE). The data is a repeated cross-section and covers urban areas. The data provide information on earnings, number of hours worked in a week, demographic characteristics (age, gender, marital status, family background, educational attainment, literacy, occupation, job type), sector of employment, and region. The survey includes information on about 18,000 to 36,000 workers in a year. ${ }^{5}$ The industry of employment is reported at the 2-digit ISIC level, which gives us 33 industries per year.

We use the household survey to create several variables. We construct an hourly wage based on the reported earnings and the number of hours worked normally in a week. Using the information on the highest completed grade, we define four education indicators: no completed education, completed primary school, completed secondary school, completed college (university degree). We distinguish between seven occupation categories: professional/technical, management, personnel, sales, service workers and servants, blue-collar workers in agriculture/forest, blue-collar industry workers. In addition, we control for whether an individual works for a private company, government, a private household, or whether a worker is an

\footnotetext{
${ }^{5}$ We have excluded all workers for which one or more variables were not reported.
} 
employer or is self-employed. Descriptive statistics for each year of the data are provided in Table $1 b .^{6}$

Of particular interest in this table are the percentages of workers belonging to the various education groups. First, note the low proportion of individuals with completed college education. Second, the table indicates that while the proportion of individuals with college education and high school degrees increases during our sample period, Colombia, like other countries in Latin America, lags behind the economies of South East Asia in terms of human capital accumulation. Moreover, there are no signs that the gap is closing. This is consistent with the evidence presented in other papers. Attanasio and Szekely (2000) show that in the cohort of individuals born between 1955 and 1959, the proportion of individuals with at least secondary education is about 40\% in Mexico and Perú, while Nuñez and Sanchez (2001) report that for the same Colombian cohort, the number is between 30 and 40\%. In contrast, this proportion is almost twice as high in Taiwan. The aggregate numbers presented in Table $1 \mathrm{~b}$ hide sizeable cohort effects in the proportion of college educated and high school graduates. These are well documented in Nuñez and Sanchez (2001) for Colombia, and in Attanasio and Szekely (2000) for Mexico, Perú, Taiwan, and Thailand.

Our data also provide detailed information on informality and workplace characteristics unavailable in many other labor force surveys. First, the survey asks each worker whether a worker's employer pays social security taxes. ${ }^{7}$ The employer's compliance with social security tax (and thus labor market) legislation provides a good indicator that a worker is employed in the formal sector. Given that between 50 to 60 percent of Colombian workers work in the informal sector, the inclusion of information on informality seems crucial. Moreover, Colombia implemented large labor market reforms in 1990 that increased the flexibility of the labor market by decreasing the cost of hiring and firing a worker (see Kugler (1999) for details). These reforms likely affected the incentives of firms to comply with labor legislation and their hiring and firing decisions, as well as the worker's choice between formal and informal employment. Descriptive statistics suggest that about 57 percent of workers worked in informal sector prior to 92. This is also the share of informal workers in 1992, however the share fluctuates significantly thereafter from .51 in 1994 to about .6 in 1996 and 1997. Furthermore, the survey provides

\footnotetext{
${ }^{6}$ One potential shortcoming of the data on worker's characteristics is the lack of information on the union status. Edwards (2001) suggests that unions are ineffective in most industries. See also the discussion in section 7.

${ }^{7}$ This information is not available in 1984.
} 
several workplace characteristics. We create four indicator variables to capture whether a worker works alone, whether the worker works in an establishment with 2 to 5 people, 6 to 10 people, or 11 or more people. We also use an indicator for whether a worker works in a permanent establishment in a building (as opposed to outdoors, kiosk, home, etc.). These workplace characteristics potentially control for differences in the quality of the workplace across industries.

\section{Measuring Inequality over 1984-1998}

\subsection{Basic trends}

We start by asking the basic question of whether inequality has increased over our sample period. We use two measures of inequality. The first one is the standard deviation of the $\log$ wages. The second one is the difference between the $90^{\text {th }}$ and $10^{\text {th }}$ percentile of the log wage distribution. The aggregate trends are documented in Table $2 \mathrm{a}$.

Both the standard deviation of the log wages and the difference between the $90^{\text {th }}$ and the $10^{\text {th }}$ percentile suggest a modest increase in inequality between 1990 and 1996, and a substantially larger increase between 1996 and 1998. In interpreting these trends, it is important to remember that our sample is confined to the urban sector in Colombia, which accounts for approximately $85 \%$ of the Colombian labor force. Accordingly, our inequality measures do not adequately capture changes in the wage distribution that may result from changes in the relative incomes of rural workers; as Johnston (1996) has shown, this may result in underestimating the overall change in inequality. A further trend that is visible from table $2 \mathrm{a}$ is that the increase in the 90-10 differential over 1990-1996 is less pronounced than the increase in the standard deviation. This indicates that most of the change in the standard deviation of the log wages is accounted for by changes in the wages of the top $10 \%$ of the population. Given that these top $10 \%$ are comprised primarily of college educated workers (the percentage of college educated individuals in our data ranges between 7 and 14\%), it is likely that the increase in the wage dispersion can be partially accounted for by an increase in the returns to college education. The experience in other developing countries, especially Mexico, that experienced a large increase in the college premium in the aftermath of trade reforms, reinforces this interpretation. We investigate the relevance of this explanation more rigorously later in the paper.

To get a preliminary idea of whether changing returns to education are responsible for the increase in inequality, we compute how inequality has changed within well-defined educational 
groups. In particular, we distinguish between three groups: workers with completed primary, or less than primary education; workers with completed secondary education (and maybe some college); and workers with completed college education. For each group we compute the standard deviation of the log wages within the group, and the difference between the $90^{\text {th }}$ and $10^{\text {th }}$ percentiles. The results are displayed in Table $2 \mathrm{~b}$.

The basic conclusion that we draw from these results is that within group inequality increased over 1990-1996 for all three groups, with the college-educated group exhibiting the largest increase. Though the increase in the inequality measures for the college-educated group may be exaggerated by changes in the top coding procedures in the NHS in the early 1990s, the message the results in Table $2 \mathrm{~b}$ send is clear: the college premium alone cannot explain the increase in wage dispersion. Other factors, such as industry effects, or changing returns to occupations, are potentially important.

\subsection{Factor returns}

To investigate the contribution of alternative explanations in explaining wage dispersion in Colombia over this period, we regressed log wages in each year against a series of demographic controls, educational, occupational, and industry dummies, and workplace characteristics. Under certain assumptions, the coefficients in these Mincer-type regressions can be interpreted as the prices of different factors at different points in time. The results from these regressions are displayed in Table $3 .^{8}$

The results in table 3 can be used to inform the investigation of inequality in two ways. First, the increase in the $\mathrm{R}^{2}$ of the regression as we successively include more controls gives some indication as to which factors contribute most to explaining the variance of log wages. The problem of course with this inference is that the covariates tend to be highly correlated with each other, so that the contribution to the increase in the $\mathrm{R}^{2}$ will depend on the order in which we add controls. Nevertheless, one can obtain a rough idea as to whether there is a set of controls (e.g.,

\footnotetext{
${ }^{8}$ Because workplace variables and informality were not available for 1984 , table 3 omits 1984 . We have also estimated table 3 for all years without workplace characteristics. Without such controls, our estimates of the college premium increase. This is intuitive since college educated workers work primarily in the formal sector, and wages in the formal sector are higher. The college premium then also captures the premium of working in the formal sector. Moreover, we have also repeated the analysis only for males in an effort to eliminate the impact of selection effects that are potentially important in female labor supply. The main difference between the full and the male-only samples seems to be the magnitude of the estimated return to college education, which is higher for males only. Nevertheless, the trends across years remain robust across the different samples.
} 
occupational dummies or industry dummies) that seems to have particularly high explanatory power. Our experimentation with various specifications in the above regressions failed to isolate such a set of variables. In terms of our inequality discussion this implies that there is not a single factor that we can attribute the increase in inequality to, but that the increase in inequality is the result of several forces working in the same direction.

Second, by examining the change in the coefficients across years, we can get a preliminary idea as to which returns to which worker characteristics seem to have changed most over this period. Given the experience in other developing countries, and the theoretical literature on the effects of trade policy, there are four sets of variables that seem a-priori likely to have been affected by the reforms:

(1) Returns to education. Between 1986 and 1998, the return to college education increases by ca. $11 \%$ relative to the return to the lowest educational category (less than primary school); for the period 1990-1998, the effect is even larger (20\%). The returns to secondary and primary education remain relatively stable in comparison.

(2) Industry wage premiums. These are captured through industry dummies in each year. While these dummies are not displayed in the tables for expositional reasons, the low correlation of their estimates across years suggests that industry premiums have changed substantially during this period, possibly because of the reforms.

(3) Returns to Occupations. In their study of the Mexican trade liberalization, Cragg and Epelbaum (1996) report significant changes in the returns to specific occupations, in particular professionals and managers. In fact, changing returns to occupations explain in Mexico a large fraction of the changing return to the college premium. However, this does not seem to be the case in the Colombian data. The returns to various occupations remain relatively stable over the 1986-1994 period; the stability of the returns to professionals in particular is in sharp contrast with the pattern reported for Mexico. Only in 1992 there is a substantial increase in the return to managers. This is intuitive, and consistent with the interpretation given by Cragg and Epelbaum for a similar finding for Mexico: During periods of substantial economic reforms managerial talent is in high demand. Since the Colombian reforms were concentrated in the 1991-1993 period, the increase in the managerial premium in 1992 is consistent with an increase in demand for managerial skill. Nevertheless, this increase gets reversed in later years, and it is not by itself sufficient to explain the overall increase in wage dispersion. 
(4) Informality. The negative coefficients on the informality dummies imply that workers employed in the informal sector earn less than workers with similar characteristics in the formal sector throughout our sample period. However, the informality "discount" varies substantially across years. From 1986 to 1994, the difference between the compensation of formal and informal workers gradually declines; from 1994 on, however, the informality discount starts increasing, and it reaches unprecedented magnitudes in 1996 and 1998. At the same time, the informal sector seems to expand in the later years of our sample (the share of informal employment rises from $56-57 \%$ to $59-60 \%$ ). These trends contribute to the rise in inequality since the informal sector employs a higher fraction of low-wage workers.

Given these patterns we focus our discussion in the rest of the paper on three sets of variables: the skill premium, the industry premiums, and the informality discount. In each case, we start our discussion by indicating what the predictions of trade theory are regarding the effects of trade liberalization on each of the above variables. Next, we contrast these predictions with the data. We do not devote further attention to returns to occupations, both because (with the exception of the return to managers in 1992) these do not seem to substantially change over this period, and because it is unclear how trade reforms would affect particular occupations through channels other than industry affiliation or changing returns to education.

\section{The Skill Premium}

The discussion of the evolution of the returns to education in the previous section suggests that the returns to secondary and elementary education remain stable over this period, while the return to college education increases by $21 \%$ between 1990 and 1998 . The increase in the college premium could be driven by changes in the rents of specific industries that employ a higher proportion of educated workers, or by changes in the returns to particular occupations that are highly correlated with education. To examine, to which extent the increase in the average skill premium can be accounted for by changes in occupational or industry returns, we compute in Table 4 the average returns to education based on a series of regressions, each of which controls for a different set of characteristics. The table includes two measures of educational returns: the secondary school premium relative to elementary education, and the university premium relative to elementary. If the rise in the skill premium were driven by changes in occupational returns and/or industry rents, we would expect the increase in the college premium to go down once we control for occupation and/or industry affiliation. However, this expectation 
is not confirmed in Table 4. In a regression without any industry or occupational controls, the change in the university degree-elementary premium is $16.7 \%$ between 1986 and 1998 (top panel). Controlling for both industry and occupational effects (bottom panel) reduces this increase to $14.2 \%$. This suggests that only a very small fraction of the skill premium increase can be accounted for by changes in industry premiums and occupational returns.

To put these numbers in context, it is instructive to compare them to the ones obtained by Cragg and Epelbaum (1996), who conducted a similar exercise for Mexico. The increase in the skill premium in Mexico over 1987-1993 is substantially larger than our estimate for Colombia: the return to post-secondary education relative to secondary education is reported to rise by $60 \%$ between the two years. However, a large portion of this increase is accounted for by changes in the returns to occupations, the rising returns to managers and professionals in particular. Controlling for occupation alone reduces the increase in the Mexican skill premium to $40 \%$. In contrast, the skill premium increase in Colombia is more modest, and cannot be accounted for by occupational returns.

A further exercise we conducted to investigate whether the increase in the skill premium was tied to particular sectors was to interact educational dummies with industry dummies. Most industry/college dummy interactions were insignificant. More of the interactions of industry dummies with dummies for either college or secondary education were statistically significant, but their inclusion did not affect the estimate of the average skill premium increase. Despite the fact that these interactions were individually insignificant, F-tests reject the hypothesis that they were jointly insignificant (the p-values were always 0.01 or smaller). To investigate whether there is a relationship between trade policy and changes in sector-specific skill premiums, we regressed the sector-specific skill premiums in each year (the college/industry dummy interactions) against tariffs, sector fixed effects and time indicators. If the increase in the skill premium was the consequence of trade liberalization, and if labor mobility was constrained in the short run, we would expect sectors with smaller tariff reductions to be associated with a larger increase in the (sector-specific) skill premium. All regressions, however, produced statistically insignificant coefficients. This could be interpreted as evidence that trade policy was not the primary reason for the skill premium increase. Alternatively, our results are consisted with a scenario where labor was mobile across sectors, so that the returns to education were equalized across sectors. In this latter case, trade policy might have led to an increase in the 
economy-wide skill premium, but it would not have impacted sectors with larger tariff reductions differentially. We investigate this possibility in the next section.

To summarize, the results from this section lead us to conclude that the increase in the skill premium we document in Table 3 represents an increase in the economy-wide return to college education that cannot be accounted for by sector specific or occupation specific effects. We now turn to the question of whether trade liberalization could be responsible for this change in the economy-wide skill premium.

\subsection{Was the Increase in the Economy-Wide Skill Premium Due to the Trade Reforms?}

The link between trade liberalization and changes in the economy-wide skill premium is provided by the workhorse model of international trade, the Heckscher-Ohlin model, and is companion theorem, Stolper-Samuelson. The Hecksher-Ohlin model predicts that countries will export goods that use intensively the factors of production that are relatively abundant, and import goods that use intensively the relatively scarce factors of the country. The StolperSamuelson theorem links factor prices to product prices. According to this theorem, trade affects wages only through changes in product prices. In its simple $2 \times 2$ version, the theorem states that a decrease in the price of a good will reduce the return to the factor that is used intensively in the production of this good, and increase the return to the other factor. Because trade policies change product prices, the Stolper-Samuelson theorem can be used to infer how factor prices (e.g., wages) will respond to a change in the trade regime.

While the sharp predictions of the $2 \times 2$ version of the model are typically lost in its multifactor versions, it is the logic of the Stolper-Samuelson theorem that led to the hope that trade liberalization would benefit the poor in developing countries, and thus contribute to a decrease in inequality. To illustrate the argument, consider a stylized view of the world in which there are two countries, a developed and a developing one, and two factors of production, skilled and unskilled labor. The developed country is relatively skilled-labor abundant, while the developing country is relatively unskilled-labor abundant. According to Heckscher-Ohlin, the developing country will export unskilled-labor intensive products, let's say apparel, and import skilled-labor intensive commodities, let's say manufactures. Now consider the effect of a trade barrier reduction in the developing country. The decrease in protection will lead to a drop in the price of the import sector, and a price increase in the export sector. According to Stolper-Samuelson, the price decrease in the import sector will hurt the factor that is used intensively in this sector 
(skilled labor), and benefit the factor that is used intensively in the export sector (unskilled labor). Note that the price changes affect only economy-wide, and not sector specific, returns. This is because the factors of production are assumed to be mobile across uses within the country, so that their returns are equalized across sectors; the relative price increase in the export sector leads to an increase in the demand for the factor that is used intensively in this sector (unskilled labor) and hence an increase in its economy-wide return. Labor mobility (along with perfect competition and given technology) is thus an essential ingredient of this argument.

Against this theoretical background, the experience in many developing countries that witnessed an increase in the skill premium and overall inequality in the aftermath of trade liberalization, has been both a disappointment and a puzzle. How can unskilled-labor abundant countries experience an increase in the skill premium when trade barriers are reduced? This pattern seems at first in sharp contrast with the prediction of the Stolper-Samuelson theorem.

We argue that the increase in the skill premium in Colombia is not only "not puzzling", but also perfectly consistent with the Stolper-Samuelson theorem. The reason is simply that the sectors that experienced the largest tariff reductions (and hence the largest reductions in the price of their output) were precisely the sectors that employed a higher fraction of unskilled workers. This is shown clearly in Figure 1 that plots the tariff decline between 1984 and 1998 for each industry against the share of unskilled workers in 1984 (unskilled is defined as having at most complete primary education). The graph shows a positive correlation between the size of tariff reductions and the share of unskilled workers. A regression of the annual change in tariffs against the share of unskilled workers in 1984 yields a coefficient of -.092 for the share of unskilled workers (t-statistic $=-2.4$ ), and an $\mathrm{R}^{2}$ of .18 (unlike in Figure 1, tariff cut is a negative number in this regression). It is interesting to note that Hanson and Harrison (1999) report a similar pattern for Mexico. Given this evidence, the increase in the skill premium is exactly what Stolper-Samuelson would predict: since trade liberalization was concentrated in unskilledlabor-intensive sectors, the economy-wide return to unskilled labor should decrease. ${ }^{9,10}$

\footnotetext{
${ }^{9}$ What is perhaps more surprising (and inconsistent in some sense with the simple $2 \times 2$ version of the HeckscherOhlin model) is the fact that it was the unskilled-intensive sectors that were heavily protected prior to the reforms. These sectors (especially textiles and apparel, and wood and wood products) are characterized by low imports. This pattern of protection could be explained within a political economy model of protection such as Grossman and Helpman (1994), or alternatively, by an extension of Heckscher-Ohlin to a three-factor (natural resources, unskilled, and skilled labor) version (see Wood (1999) and Leamer et al (2002)).

${ }^{10}$ Given that the most protected sectors are unskilled-labor intensive, these sectors are potentially net exporters producing differentiated products. Lower tariffs are likely to lead to lower wages even in the presence of product
} 
While the above argument demonstrates that the rise in the skill premium documented in the previous section could in principle be attributed to the trade reforms, it does not of course constitute proof that it was the trade reforms that led to this rise. In search for Stolper-Samuelson effects on wages we take an indirect route. We check whether there is evidence that the general equilibrium adjustment mechanism suggested by the Heckscher-Ohlin model is at work. The mechanism at the heart of the Heckscher-Ohlin model implies a contraction of the sectors that experience a (trade-barrier reduction induced) decline in their output price, and an expansion of the sectors that experience a relative price increase. Accordingly, we would expect to see labor reallocation from the sectors with the largest tariff reductions to the sectors with the smaller tariff reductions. The left panel of table 5 shows the industry shares in total employment in 1984 and in 1998. These shares remain remarkable stable. There is certainly no evidence of labor reallocation across sectors. Regressing industry employment shares on industry tariffs, industry, and time indicators confirms this conclusion: the tariff coefficient is small in magnitude (0.01) and statistically insignificant. In sum, the employment patterns over 1984-1998 are not consistent with an explanation that would attribute the rise in the skill premium to changes in trade policy, operating through Stolper-Samuelson effects. Even though more general versions of the model fail to deliver the sharp predictions of the $2 \times 2$ version, it is remarkable that in the face of large, and differential tariffs reductions we see virtually no change in employment shares across sectors.

We should note that the stability of the employment patterns is consistent with the evidence from Mexico; Revenga (1997), Hanson and Harrison (1999), and Feliciano (2001) all report that the adjustment of the Mexican labor market to trade liberalization occurred through relative wage adjustments and not through labor reallocation across sectors. This adjustment process contrasts with the evidence from the United States, where Grossman (1986) and Revenga (1992) find greater employment than wage sensitivity to trade shocks. The differences in the adjustment mechanisms of Colombia and Mexico on one side, and the U.S. on the other, are suggestive of greater labor mobility in the United States compared to the other two countries.

differentiation and intra-industry trade, as long as lower tariffs are not counterbalanced by higher export prices in this sector. Because Colombia is a small country and it experienced a drastic unilateral liberalization during our study, it is unlikely that trade liberalization was accompanied by a rise in export prices. 
This is consistent with the view that labor market rigidities in developing countries might obstruct labor reallocation in response to economic reforms.

Finally, if Stolper-Samuelson forces were at work, firms would substitute away from skilled labor with the rising skill premium, and we would expect to see the share of skilled labor in industry employment decline. The right panel of Table 5 reports the share of skilled workers in each industry and shows that this share has increased substantially in every industry between 1984 and 1998. This evidence is hard to reconcile with Stolper-Samuelson effects as the primary mechanism leading to the rise in the skill premium. Instead, table 5 seems more consistent with skilled-biased technological change. ${ }^{11}$ Evidence from several countries seems to suggest that the latter has had important effects on the wage distribution in the last two decades (see Berman, Machin, and Bound (1998), Pavcnik (2003)). However, the evidence in favor of skilled-biased technological change does not imply that trade policy did not have an indirect effect on changes in the wage distribution. To the extent that technological change was an endogenous response to intensified competition from abroad (see Acemoglu 2002 $\mathrm{a}^{12}$ ), one could argue that the trade reforms were indirectly responsible for the increase in the skill premium.

To investigate this claim, we regress in Table 6 the share of skilled workers in each industry against industry tariffs, industry and time indicators. Table 6 reports the LS results and 2SLS to account for the potential endogeneity of trade policy (for example, in setting tariffs, policy makers could be taking into account industry characteristics, such as the share of skilled or unskilled workers, wages, etc.). To find appropriate instruments for tariffs we rely on the history of protection in Colombia and the institutional details of the reforms. Anecdotal evidence and World Bank reports suggest that the Colombian government initiated liberalization in response to exchange rate fluctuations and the trade balance. The trade balance in Colombia

\footnotetext{
${ }^{11}$ Leamer has made the argument in several papers that it is sector-bias, and not factor-bias that is relevant for the income distribution. Skilled-biased technological change that is concentrated in unskilled-intensive sectors would benefit unskilled workers in the general equilibrium, while skilled-biased technological change concentrated in skilled-intensive industries would benefit skilled workers. Motivated by this argument we regressed the annual change in the share of skilled workers in each industry on the initial skill intensity of the industry in 1984. A positive coefficient would suggest bias that would favor skilled workers (skilled-biased technological change would be more pronounced in sectors that are initially skill-intensive). However, this regression did not produce a statistically significant coefficient. If anything, the negative sign of the "initial skill-intensity" coefficient would suggest the presence of skilled-biased technological change that is concentrated in low-skill sectors. Note, however, that Leamer's argument rests on the assumption of fixed product prices, which is unlikely to hold during trade liberalization.

${ }^{12}$ This argument is also related to Wood (1995) and to the more recent paper by Thoenig and Verdier (2002) See also the survey by Acemoglu (2002b).
} 
has in turn always been heavily influenced by world coffee prices (see Roberts and Tybout (1997)), since coffee is a major export of this country. This indicates that at the macroeconomic level, exchange rates and world coffee prices are some of the factors responsible for the trade policy changes. However, exchange rates or coffee prices alone cannot explain why some sectors experienced larger tariff reductions than others. In explaining the latter, two facts seem of importance. First, before the onset of trade liberalization, there was substantial tariff dispersion across sectors. As discussed earlier, in examining the cross-sectional pattern of protection we find that the single most important determinant of tariff levels was the share of unskilled workers: sectors with a high share of unskilled workers (where unskilled is defined as having at most primary education) had higher tariffs. Second, the Gaviria government was committed to economy-wide liberalization and aimed at reducing tariffs to the levels negotiated within the WTO. As a result, the final tariff rate was almost uniform, implying that there was little (if any at all) room for industry lobbying ${ }^{13}$; from an individual industry's point of view, the tariff rate at the end of the trade liberalization period was exogenously predetermined. This policy translated to proportionately larger tariff reductions in sectors that had historically higher tariff levels. The close link between the magnitude of tariff reductions and the initial level of protection in 1983 (a year prior to our sample) is evident in a regression that relates the 1998-1984 tariff reductions to the 1983 tariff levels: it yields a coefficient on the 1983 tariff of 1.06 (with a T-statistic of 26.3) and an $\mathrm{R}^{2}$ of .97 . This discussion suggests that the 1983 industry tariff levels, and their interaction with exchange rates (or coffee prices), are highly correlated with the industry tariff reductions and may provide good instruments for the tariff changes. ${ }^{14}$

The results in columns 1-3 of Table 6 indicate that the share of skilled workers in each industry is inversely related to protection; industries with larger tariff reductions experienced more rapid skill-biased technological change, as measured by the proportion of skilled workers. ${ }^{15}$ We also estimate the relationship between the share of skilled workers and tariffs in first differences and those results are reported in columns 4-6. These results confirm the negative association between skill-biased technological change and tariff changes (but are at time

\footnotetext{
${ }^{13}$ In reality, some dispersion in tariff rates remained even after the trade reforms, but this dispersion is substantially smaller than the pre-reform tariff rate dispersion. See standard deviations in table 1a.

${ }^{14}$ The exchange rate we use is the nominal effective rate (source: IMF) that is computed taking into account Colombia's major trade partners. IMF is also the source of coffee prices.

${ }^{15}$ Note that we cannot include the 1983 tariffs as an instrument in industry fixed effects 2 SLS regressions because the variable is time-invariant. As a result, we only use the interaction of the 1983 tariffs with the exchange rate (coffee prices) as an instrument.
} 
imprecisely estimated). Overall, the evidence in Table 6 is consistent with what Adrian Wood has labeled "defensive innovation"; firms in sectors facing intensified import competition (and these, in Colombia, are the sectors employing more unskilled workers) look for new methods of production that economize on unskilled labor.

In summary, our results suggest that the increase in the skill premium cannot be linked to developments in particular sectors of the economy - it was an economy-wide phenomenon. While this, in principle, opens the door for Stolper-Samuelson effects, we find no evidence of the labor reallocation mechanism across sectors that should accompany such effects. However, we do find evidence in favor of skill-biased technological change, which was more rapid in sectors that experienced larger tariff reductions. To the extent that skilled-biased technological change was induced, at least partially, by changes in the trade regime, we conclude that trade liberalization may have had an indirect effect on the rise of the skill premium.

\section{Effects of Trade Reforms on Industry Wage Premiums}

\subsection{Theoretical Background and Methodology}

As noted in Section 3, changes in the economy-wide returns to education can only partially explain the increase in inequality, since wage dispersion also increases within each educational group. To explain the rise in the within group inequality, we now turn to the role of other factors, such as changing industry wage premiums. Our focus on industry premiums is motivated by two considerations.

First, our empirical results suggest that industry premiums (captured through industry dummies in the regressions of Table 3) change substantially over this period. Year-to-year correlations of industry premiums are as low as 0.14 . This contrasts sharply with the evidence on wage premiums in the U.S., where wage premiums have been shown to be stable across years (year-to-year correlations are always estimated to be above 0.9 ). ${ }^{16}$ This raises the possibility that the trade reforms changed the structure of industry wages.

Second, there are good theoretical reasons to believe that trade reforms that changed the structure of protection would affect relative, and not only economy-wide, wages. The focus on economy-wide returns that underlies our discussion of the skill premium is premised on the assumption that labor is mobile across sectors. Yet, this is an assumption that is unlikely to hold,

\footnotetext{
${ }^{16}$ See Dickens and Katz (1986), Krueger and Summers (1987) and (1988), Katz and Summers (1989), Gaston and Trefler (1994).
} 
especially in the short- and medium-run, and in developing countries like Colombia, where labor markets are characterized by significant labor rigidities. Indeed, our results on employment shares in Table 5 suggest limited labor mobility across sectors. In addition, there is substantial evidence that wages for observationally equivalent tasks differ across industries; this interindustry variation is hard to reconcile with the assumption of perfect factor mobility.

The perhaps most natural point of departure for thinking about the effects of trade on relative wages is the specific factors model. This model is short-run by nature as it considers factors of production immobile across sectors. It predicts that sectors that experienced relatively large tariff cuts will see a decline in their wages relative to the economy-wide average, while sectors with proportionately smaller trade barrier reductions will benefit in relative terms. The medium-run (Ricardo-Viner) model yields similar predictions. Note that these implications of models with constrained factor mobility differ from the ones of the Hecksher-Ohlin model, which predicts that trade reform should affect only economy-wide returns to the factors of production, but not industry specific returns, since all factors of productions are mobile across uses.

It is important to note that the above trade models assume perfectly competitive product and factor markets. The existence of industry wage premiums is hence perfectly consistent with perfect competition in the presence of industry specific skills. Introducing imperfect competition opens up additional channels through which trade policy may impact wages. In the presence of unionization, it is possible that unions extract the rents associated with protection in the form of employment guarantees rather than wages (an idea developed in Grossman (1984)). Liberalization induced productivity changes may further impact relative wages. There is by now a voluminous literature on the effects of trade reform on firm productivity. While in theory the effects of liberalization on productivity are ambiguous (see Rodrik (1991) and Roberts and Tybout $(1991,1996)$ for a discussion), most empirical work to date has established a positive link between liberalization and productivity (Harrison for Cote d' Ivoire (1994), Krishna and Mitra for India (1998), Kim for Korea (2000), Pavcnik for Chile (2002)). For Colombia specifically, Fernandes (2001) estimates that the trade reforms up to 1992 had a significant impact on plant level productivity. To the extent that productivity enhancements are passed through onto industry wages, we would expect wages to increase in the industries with the 
highest productivity gains. If these occur in the industries with the highest trade barrier reductions, industry wages would be positively correlated with trade liberalization.

The discussion above suggests that, based on theoretical considerations alone, it is not possible to sign the effect of trade liberalization on industry wages unambiguously. To investigate this effect empirically, we employ a two-stage estimation framework familiar from the labor literature on industry wages. In the first stage we regress the log of worker i's wages $\left(\ln \left(\mathrm{w}_{\mathrm{ijt}}\right)\right)$ on a vector of worker characteristics $\mathrm{H}_{\mathrm{ijt}}$ (age, age squared, gender, marital status, head of the household indicator, education indicators, literacy, location indicator, occupational indicators, job type indicators, born in urban area indicator, time in residence, urban birth*time in residence) and a set of industry indicators $\left(\mathrm{I}_{\mathrm{ijt}}\right)$ reflecting worker i's industry affiliation (the regressions reported in Tables 3 correspond to this stage of the estimation): ${ }^{17}$

$$
\ln \left(w_{i j t}\right)=H_{i j t} \beta_{H t}+I_{i j t} * w p_{j t}+\varepsilon_{i j t}
$$

The coefficient on the industry dummy, the wage premium, captures the part of the variation in wages that cannot be explained by worker characteristics, but can be explained by the workers' industry affiliation. Following Krueger and Summers (1988), we normalize the omitted industry wage premium to zero and express the estimated wage premiums as deviations from the employment-weighted average wage premium. ${ }^{18}$ This normalized wage premium can be interpreted as the proportional difference in wages for a worker in a given industry relative to an average worker in all industries with the same observable characteristics. The normalized wage differentials and their exact standard errors are calculated using the Haisken-DeNew and Schmidt (1997) two-step restricted least squares procedure provided to us by John P. HaiskenDeNew and Christoph M. Schmidt. ${ }^{19}$ The first stage regressions are estimated separately for each year in our sample as the subscript $t$ in equation (1) indicates. In the second stage, we pool the industry wage premiums $\mathrm{wp}_{\mathrm{j}}$ over time and regress them on a vector of trade related industry characteristics $\mathrm{T}_{\mathrm{jt}}$, and a vector of industry fixed effects, and time indicators $\mathrm{D}_{\mathrm{jt}}$ :

$$
w p_{j t}=T_{j t} \beta_{T}+D_{j t} \beta_{D}+u_{j t}
$$

\footnotetext{
${ }^{17}$ We have also experimented with several other specifications (see Goldberg and Pavcnik (2003a)). The overall conclusions are similar to those reported in this paper. Moreover, the above specifications were estimated using both the log of the weekly earnings and the log of hourly earnings as dependent variables. The wage premiums based on these two definitions were highly correlated. We therefore focus our discussion on hourly wage premiums.

${ }^{18}$ The sum of the employment weighted normalized wage premiums is zero.

${ }^{19}$ Haisken DeNew and Schmidt (1997) adjust the variance covariance matrix of the normalized industry indicators to yield an exact standard error for the normalized coefficients.
} 
We also estimate the second-stage regression in first-differences. ${ }^{20}$ Since the dependent variable in the second stage is estimated, we estimate (2) with weighted least squares (WLS), using the inverse of the variance of the wage premium estimates from the first stage as weights. This procedure puts more weight on industries with smaller variance in industry premiums. We account for general forms of heteroskedasticity and serial correlation in the error term in (2) by computing robust (Huber-White) standard errors clustered by industry.

\subsection{Second-stage Results and Their Implications for Wage Inequality}

Table 7 reports results from relating the wage premiums to tariffs. The industry fixed effects results are presented in columns 1-2. First-differences results are presented in columns 34. Because the two specifications yield similar findings, we focus our discussion on the firstdifferences results. The coefficient on tariff in column 3 is negative and significant. This implies that increasing protection in a particular sector raises wages in that sector. The magnitude of the effect is also significant and suggests that a 50-percentage point reduction in tariffs $(.5)$ translates to a $6 \%(.1191 * .5)$ decrease in the wage premium in this sector. For the most protected sectors ( $91 \%$ tariff) this effect increases to $10.8 \%(0.1191 \times .91)$.

Note that because we condition our industry wage premium estimates on worker characteristics in the first stage, our estimates of the relationship between tariffs and wages are not driven by observable differences in worker composition across industries that also affect industry ability to obtain protection. Moreover, to the extent that political economy factors and sorting based on unobserved worker attributes are time-invariant, we control for them through industry fixed effects or through first differencing. Assuming that political economy determinants of protection do not vary much over relatively short time periods seems a reasonable identification assumption in many cases. However, given that the structure of protection changes over our sample period, time-variant political economy considerations are expected to be important. For example, if protection responds to exchange rate pressures, and exchange rates also have a direct effect on wages, one would expect the tariff coefficient to be biased. Albeit the year effects included in (2) already control for the aggregate effects of

\footnotetext{
${ }^{20}$ Alternatively, we could combine the regressors in (1) and (2) and estimate the relationship between wages and tariffs directly in one stage. In fact, we have implemented this one-stage approach, and the coefficient on tariff was .081 and highly significant. However, because our individual level data are a repeated cross-section, we cannot estimate the one-stage regression in first-differenced form. The main reason that we focus on the two-stage approach is that it allows us to difference the industry level data (our preferred specification).
} 
exchange rates (and other economy-wide shocks), unobserved industry specific time-varying shocks could still bias our estimates. We address this concern in two ways.

First, we control for variables such as lagged imports and exports, and their interactions with the exchange rate. Because trade flows are arguably endogenous (they depend on factor costs), we include the first lags of import and export measures in the estimation rather than their current values. ${ }^{21}$ We interact the exchange rate with lagged trade flows because a-priori we would expect the effects of currency fluctuations to vary depending on the trade exposure of the sector. The first-differences results are reported in column 4 of table 7 . The inclusion of these additional controls hardly changes the coefficient on tariffs.

Second, we account for the potential endogeneity of trade policy changes by instrumenting for tariff changes in the first-differences specification with the pre-sample protection measures (1983 industry tariff levels), and their interaction with exchange rates (and world coffee prices). ${ }^{22}$ Columns 5-8 of Table 7 contain the 2 SLS results. Although the magnitude of the tariff coefficient changes, the positive (and statistically significant) relationship between tariff reductions and declines in industry wage premiums is robust. The estimated effect of liberalization on wages drops however from .119 in column 1, to .05 in column 7 . The coefficient of .05 implies that a 50-point tariff reduction would lead to a 2.5 percent decline in wage premiums. Moreover, while the year indicators already control for the direct aggregate effect of the exchange rate on wages, direct industry-specific exchange rate affect could still potentially bias our 2SLS estimates (especially those that use exchange rate interacted with 1983 tariffs as an instrument). This omitted bias is however unlikely important because the coefficient on tariffs hardly changes in columns 2 and 4 (relative to columns 1 and 2) after we control for the interactions of the exchange rate with lagged exports and imports. Nevertheless, column 8 reports the 2SLS specification that includes lagged imports and exports and their interactions with the exchange rate as controls and uses world coffee prices interacted with 1993 tariffs and

\footnotetext{
${ }^{21}$ Of course, to the extent that imports and exports are serially correlated, this approach does not completely eliminate simultaneity bias. While we fail to reject that there is no serial correlation for exports, we reject the test of no serial correlation in the case of imports (rho is .27 with $\mathrm{p}$ value of .001). However, the specification that includes imports as a control variable is merely a robustness check and the coefficient on tariffs is not sensitive to the inclusion of imports.

${ }^{22}$ See the discussion in section 4.1 that motivates the choice of instruments.
} 
1993 tariffs as instruments. We continue to find that tariff declines are associated with declines in wage premiums.

These results suggest that trade policy had a significant effect on relative wages. Workers employed in industries with larger tariff reductions experienced a decline of their wages relative to the economy-wide average. This by itself does not imply an increase in inequality. If the industries with the larger tariff reductions had been the industries with the initially highest wage premiums, then trade policy would have reduced wage dispersion. However, our findings suggest exactly the opposite pattern. The sectors that experienced the largest tariff reductions were in fact the sectors with the highest shares of unskilled workers, and lowest wages (see section 4.1 and Figure 1). In the manufacturing sector in particular, where most of the trade liberalization was concentrated, the lowest wage premiums are estimated in textiles and apparel, food processing, and wood and wood processing, all sectors that were heavily protected prior to the reforms, and experienced the largest tariff cuts. In particular, textiles and apparel had tariff cuts around 73 percentage points between 1984 and 1998, while the tariff reductions in food processing and wood and wood processing were 29 and 49 percentage points respectively. These tariff reductions are to be contrasted with the ones in the high wage premium sectors of coal mining (tariff cut: 11 percentage points) and crude petroleum (tariff went actually up by 4 percentage points).

The negative relationship between tariff reductions and pre-reform wage premiums is also illustrated in Figure 2 that plots tariff reductions between 1984 and 1998 against the wage premiums in the first year of our sample, 1984. A regression of annual tariff reductions against wage premiums in 1984 confirms the impression conveyed by Figure 2: the wage premium coefficient is negative and statistically significant (coefficient: -.064; p-value: .069) indicating that the larger the wage premium the smaller the tariff cut (note tariff cuts are positive numbers in this regression). The trade reform induced changes in the wage premiums could thus only increase inequality.

\section{Effects of Trade Reforms on Informality}

As noted in section 3, trade reforms could lead to an increase in inequality by expanding the size of the informal sector. In Colombia, the informal sector employs 50 to 60 percent of the 
labor force and has been expanding during the 1990s. ${ }^{23}$ The presence of a large informal sector provides an additional margin through which labor markets can adjust to external shocks in developing economies. An emerging concern in many Latin American countries is that trade liberalization has contributed to the rise in the number of informal workers (Stallings and Peres (2000)). In particular, opponents of globalization have argued that firms exposed to increased international competition may try to reduce costs by cutting worker benefits. To do this, large and medium-sized firms, or multinationals, may outsource activities to small, informal firms, including home-based and self-employed microenterpreneurs. Alternatively, they may replace permanent, full-time workers, with temporary and/or part-time labor. Currie and Harrison (1997), for instance, indeed find that after the trade liberalization in Morocco firms started hiring more temporary workers. Consistent with this view, Goldberg and Pavcnik (2003b) present a theoretical model that formally shows that permanent trade liberalization can result in an increase in the informal employment.

Because the informal sector does not provide benefits and it is believed to provide lower job quality, a trade reform induced rise in informality may then contribute to the rise in inequality, where inequality is broadly defined as the gap between those who have well paid jobs with benefits and high job quality, and those who face lower wages, no benefits, and worse workplace conditions. This claim is controversial. There is a large literature that claims that employment in the informal sector is voluntary and should not therefore be considered an inferior option. However, a special module in the 1994 NHS contains questions about work conditions and job satisfaction that allow us to assess the validity of the claim that informality is associated with lower job quality. We find that working in the informal sector is indeed negatively correlated with job satisfaction, good workplace conditions, good employee relations, and job training. The negative correlation between informality and various measures of job quality suggests that it is potentially important to account for the informal sector in a study of inequality.

While the concerns about informality have received a lot of attention recently, there is no sound empirical evidence linking the trade reforms to the increase in informal employment and

\footnotetext{
${ }^{23} \mathrm{An}$ interesting feature of the Colombian data is that informality is present in all industries. This contrasts with the widely held view that informality is a feature of specific sectors, such as wholesale and retail trade. While these sectors do have the highest shares of informal workers in our sample (76 and 67\% respectively), the share of informal employment in manufacturing is $48 \%$. Moreover, this share has increased over time in manufacturing, peaking in 1996 and 1998.
} 
addressing the possible effects increased informality may have on wage inequality. Our data set with its detailed information on the informal sector is ideal for filling in this gap. As described in section 2.2, the main criterion we use to assign firms to the informal sector is compliance with labor market regulation. The NHS June waves ask workers whether their employer contributes to social security. This information is an excellent proxy for formality, as it indicates whether or not the employer complies with labor legislation. Furthermore, this definition has an obvious appeal to trade economists as it relates to the debate on how labor standards/legislation affect prices of tradable goods, and trade flows.

We examine the claim that trade liberalization leads to an increase in informality by employing a two-stage empirical framework similar to the one in section 5, but with an indicator for whether a worker is employed in the informal establishment as the dependent variable. In the first stage, the informality indicator is regressed against the same regressors as in equation (1). The coefficient on the industry indicator captures the variation in the probability of informal employment that cannot be explained by worker characteristics, but can be explained by workers' industry affiliation. We can these coefficients industry informality differentials. We then express the informality differentials as deviation from the employment-weighted average informality differential. This normalized informality differential can be interpreted as the percentage point difference in probability of informal employment for a worker in a given industry relative to the average worker in all industries with the same observable characteristics. Equation (1) is estimated separately for each year of our sample. In the second stage, we pool these industry informality differentials across years and relate it to trade policy as in equation (2). If the likelihood of employment in the informal sector increases with the magnitude of the tariff reductions, trade liberalization will have contributed to the increase in informality.

We should note that it is crucial to exploit both the cross-industry and time variation in the trade policy changes to look at how informality relates to trade reforms. During the early 1990s Colombia implemented labor reforms that are thought to have significantly reduced the rigidities in the formal labor markets and to have contributed to a shift from the informal to the formal sector (Kugler (1999)). The use of the cross-sectional and time variation in the trade policy changes enables us to separate the effects of industry specific trade policy changes from the effects of economy-wide labor reforms. All our specifications include year indicators, which capture the effect of economy-wide labor reforms, exchange rates, and other macro shocks. In 
addition, as is the case in the analysis of wage premiums, because we condition our industry informality differential estimates on worker characteristics in the first stage, our estimates of the relationship between tariffs and informality are not driven by observable differences in worker composition across industries that also affect industry ability to obtain protection. Finally, industry fixed effects (or first-differencing) control for the unobserved time-invariant industry (or worker) characteristics that might independently affect informality and tariffs.

Table 8 presents the findings. Columns 1-3 report the results from the industry fixed effects regressions. In all specifications the effect of tariffs on informality is negative and significant. To interpret the size of the tariff coefficients, consider an industry from the manufacturing sector with an average level of tariffs in 1998 (13\%). Suppose that we conducted the conceptual experiment of reducing tariffs to zero in this industry. Then the estimated coefficient in column 1 suggests that the probability of this worker having an informal job would rise by 1.1 percentage points $(0.13 \times$.087). The corresponding effect in 1984 , when the average tariff was $50 \%$, would be 4.4 percentage points $(.5 * .087){ }^{24}$

Increased exposure to foreign markets could affect the probability of informal employment through channels other than tariff reductions such as import competition. Column 2 of Table 8 reports the results from regression specifications that include the first lags of imports and exports. The results contain two noteworthy findings. First, the tariff coefficient seems robust to the inclusion of the additional trade controls. Second, the positive sign on the coefficient on imports suggests that the probability of informal employment increases when an industry faces higher import penetration. This supports the view that increased foreign competition forces domestic firms to become more competitive and reduce cost by either subcontracting in the informal sector or by firing workers that in turn seek employment in the informal sector. In column 3 of table 8, we allow the impact of imports and exports on informality to vary with exchange rate fluctuations. We control for exchange rate fluctuations by interacting the exchange rate with lagged values of imports and exports. While the inclusion of exchange rate hardly changes the magnitude of the coefficients on tariff, the coefficients become statistically insignificant. Moreover, our results continue to suggest that probability of informal employment increases when an industry faces higher import competition.

\footnotetext{
${ }^{24} \mathrm{As}$ in the case of wage premiums, we have also estimated the relationship between informality and tariffs in onestep approach. This yielded similar conclusions as the two-stage industry fixed effects regressions. The coefficient on tariff was -.126 and highly significant.
} 
We also estimate the relationship between informality and trade policy in first-differences form and those results are reported in columns 4-6. Interestingly, while the positive association between import competition and informality continues to hold, first-differences results suggest no relationship between industry informality differentials and tariffs. In Goldberg and Pavcnik (2003b) we investigate the discrepancy between the industry-fixed-effects results and firstdifferences results further. We find that the labor market reform in 1990 that reduced the costs of firing and hiring a worker and increased labor market turnover (see Kugler (1999), Heckman and Pages (2000)) plays an important role. In particular, we allow the relationship between informality and trade policy to differ before and after the Colombian labor market reform. Those specifications yield interesting findings: Tariff reductions are associated with increases in informality before labor market reform in both the industry-fixed-effects and first-differences specifications. However, we find no statistically significant (or a small positive association) between informality and tariff changes after the labor market reform. These differences in the results indicate that labor market institutions play a potentially important role in how trade reform affects informal employment. In sum, we find that tariff declines are associated with an increase in informal employment, but only in period before the labor market reforms.

Given that the "discount" of informality increases in the later years of our sample, we also examined if this increase was driven by changes in the return to informality in specific sectors of the economy that were affected more by trade policy. To this end, we allowed in the framework described above interactions between industry premiums and informality, and related these interactions to industry tariffs. The tariff coefficients in these specifications were, however, not statistically significant, indicating that the effect of trade policy on industry wages did not vary across the formal and informal sectors. Put differently, the falling wages in the informal sector cannot be attributed to decreasing wages in the informal sectors of industries that experienced larger tariff reductions.

In summary, our results provide some suggestive evidence that trade liberalization contributed to an increase in the size of the informal sector in Colombia in the period before the labor market reform. Because jobs in the informal sector do not provide benefits and are associated with lower job satisfaction and quality of work, the rise in informality contributes to the increase in inequality.

\section{On the Role of Labor Market Institutions}


Our analysis so far has abstracted from the contributions of labor market institutions, such as minimum wages and unions, to wage inequality. Changes in the minimum wage could potentially affect the skill premium by compressing the lower end of the wage distribution. However, while evidence suggests that the minimum wages are binding in Colombia (see Bell (1997)), changes in minimum wages are of secondary importance during our sample period in Colombia. The most significant increases in the minimum wage took place in the late 1970's and early 1980's (see Bell (1997), Table 2). The changes in the late 1980's and 1990's were in comparison small. Moreover, the minimum wage is set in Colombia at the national level, so that minimum wages do not vary by industry. As a result, changes in the minimum wage cannot explain the relationship between tariffs changes and changes in wage premium (or changes in informality) in our study. Note that any effects minimum wage changes may have had on industry wages (or probability of informal employment) through compositional channels, for example because some industries employ more unskilled workers than others, are already controlled for in our approach in section 5 and 6, since the first-stage regressions control for industry composition in each year, and allow the returns to various educational and professional categories to change from year to year.

Regarding unionization, our individual level data do not provide information on the union membership of each worker. Unfortunately, detailed industry-level information on union membership is also not available. As a result, the economy-wide increases in skill premium over time documented in this paper could potentially reflect changes in union power (for example, increases in skill premium could be attributed to unions if unions usually increase the relative wages of the unskilled workers and the union power has declined over time). While in the absence of industry-level union data we cannot formally address this issue, we believe that changes in unionization are unlikely to be of concern during this period (especially in the analysis that related industry-specific tariff changes to various labor market outcomes). Anecdotal evidence suggests that unions do not have significant power in most Colombian industries (public sector and the petroleum industry are the exception). In his book on Colombian reforms, Edwards (2001) confirms these anecdotal reports. More importantly, there is no evidence (or even a claim) in the literature that union strength changed during the period of trade liberalization. We therefore believe that changes in unionization are unlikely to be driving our results. 
Finally, our discussion is premised on the existence of labor market rigidities in Colombia. While we do not attempt a formal investigation of the role of such rigidities, their existence seems apriori relevant in Colombia, a country characterized by one of the most restrictive labor market regimes in Latin America. Indicatively, Heckman and Pages (2000) report that the cost of dismissing a worker in Colombia is approximately 6 times the monthly wage at the end of the 1980's, and 3.5 times the monthly wage at the end of the 1990's (after the labor market reform). Kugler (1999) reports similar findings on the costs of firing workers in Colombia. In addition, several of our results seem consistent with the view that labor markets in Colombia are rigid, and labor market regulation is to some extent binding. For example, we fail to find big labor reallocations in the aftermath of a major trade reform, from sectors that experienced large protection declines to sectors that were less affected by liberalization: regressions of changes in sectoral employment shares on tariff changes fail to detect any relationship between trade liberalization and sectoral employment. This stability of industry employment shares seems consistent with constrained labor mobility. Still, the lack of labor reallocation seems rather surprising given the existence of a large informal sector in Colombia that does not comply with labor market regulation. One possible explanation is that labor is more mobile across the formal and informal sectors, than across industries. Indeed, in a related paper (Goldberg and Pavcnik (2003b)), we find that, while the share of informal workers increased in Colombia in the aftermath of the trade reforms, the entire increase is accounted for by within-industry changes from the formal to the informal sector, rather than by between-industry shifts of informal workers.

\section{Unemployment}

Up to this point, we have abstracted from the relationship between trade policy and transition into unemployment. Table 9 reports the unemployment rate in urban Colombia during our sample based on June waves of NHS Montenegro and Peña (2000) report similar trends in

overall unemployment based on the Department of National Planning data. Because unemployment may be an important component of the adjustment mechanism to trade shocks, at least in the short run, the natural question arises whether trade policy contributed to these unemployment changes. Table 9 suggests that the urban unemployment rate declined from about 14 percent 1984 to 9.7 percent in 1994 . Until the very end of our sample period unemployment rates were remarkably stable and particularly so during the years around the tariff cuts. Only in 
1998, at the beginning of the worst recession in Colombian recent history and with no changes in tariffs, did unemployment increase to $16 \%$.

Although the aggregate statistics seem to suggest that tariff reductions are unlikely to be the main cause of the unemployment surge during the late 1990s, inferences based on macroeconomic trends can be misleading. The link between trade policy and unemployment could be better identified by relating detailed industry tariff changes to changes in industry unemployment in an analysis parallel to the study of the relationship between informality and tariffs in section 6. Unfortunately, the lack of detailed data on industry affiliation of the unemployed in the NHS precludes such an analysis. In particular, the unemployed workers that were previously employed report the last industry of employment at the 1-digit ISIC level. Similarly, the unemployed individuals who were not previously employed report the industry in which they are seeking employment at the 1-digit ISIC level. This leads to 9 industry observations per year and only 6 out of 9 of these industries have available tariffs. Most importantly, most of the time-variation in tariffs occurred within the manufacturing industries, which are now treated as a single sector. As a result, we cannot pursue such an approach.

To get a rough idea whether trade policy changes could be associated with increases in unemployement, we instead check whether the increase in the probability of being unemployed was greater for workers employed in traded-good sectors (such as manufacturing) than for workers with the same observable characteristics in non-traded-good sectors (such as wholesale and retail trade, restaurants, hotels, construction, etc.). We perform this analysis for two years at a time, using a year before and after the major trade reforms in 1990/91. In particular, we regress an indicator for whether an individual is unemployed on 1 digit ISIC industry indicators (wholesale and retail trade, restaurants/hotels (ISIC 6) is the omitted category), an indicator for a year following the trade reform, the interaction of industry indicators with the year indicator, and a set of worker characteristics (age, age squared, male, married, head of the household, education indicators, literate, lives in Bogota, born in urban area, time in residence, urban birth*time in residence). If the probability of being unemployed increased relatively more over time in manufacturing relative to a sector such as wholesale and retail trade and restaurants and hotels (i.e. the coefficient on the interaction of the manufacturing indicator with year indicator is positive and significant), this could provide some indirect (and suggestive) evidence that trade reforms were associated with increases in the probability of unemployment. 
Table 10 presents the results. Column 1 focuses on the changes in probability of unemployment between the first and last year of our sample, 1984 and 1998 respectively. Two findings emerge. First, as expected, the coefficient on the post trade reform year is positive and significant, which reflects the aggregate increase in unemployment in Colombia during the 1990s. Second, the coefficient on the interaction of manufacturing indicator and the post trade reform indicator is negative and insignificant. This suggests that conditional on worker characteristics, the probability of unemployment did not change in a statistically different way in manufacturing sector relative to the non-traded reference sector. In fact, with the exception of the transportation sector, we find no statistical differences in changes of the probability of unemployment across industries between 1984 and 1998. This analysis seems to support the view that the probability of unemployment did not change significantly in the manufacturing sector relative to most non-traded sectors over the long run, even though the manufacturing sector experienced drastic tariff declines. However, the above analysis might potentially miss short-term adjustments to trade reform that occur during times closer to trade reform. As a result, in column 2 we consider the unemployment adjustment in periods right before and after the major tariff declines by focusing on changes in unemployment between 1988 and 1992. While the coefficient on the interaction of the manufacturing indicator with the post trade reform year continues to be negative, its magnitude increases in absolute value and is now statistically significant (this could be potentially due to exchange rate depreciation in 1990/91 that lowered the demand for nontraded goods relative to traded goods).

In sum, albeit we cannot directly identify the effects of tariff declines on the probability of employment, our data suggest that increases in the probability of unemployment before and after tariff reductions were not larger in traded sectors (such as manufacturing) than in nontraded sectors (such as wholesale and retail trade). If anything, the short-term changes in unemployment suggest the opposite.

\section{Conclusions}

In this paper we investigated the effects of the drastic tariff reductions of the 1980s and 1990s in Colombia on the wage distribution. We identified three main channels through which the wage distribution could have been affected: increasing returns to college education, changes in industry wages that hurt sectors with initially lower wages and a higher fraction of unskilled workers, and shifts of the labor force towards the informal sector that typically pays lower wages 
and offers no benefits. Our results suggest that trade policy played a role in each of the above cases. The increase in the skill premium was primarily driven by skilled-biased technological change. However, as the sectors with the largest reductions in tariffs were those with the sharpest increase in the share of skilled workers, we argue that this change may have been in part motivated by the tariff reductions and the increased foreign competition to which the trade reform exposed domestic producers.

With respect to industry wages, we find that wage premiums decreased by more in sectors that experienced larger tariff cuts. As these were the sectors with the lowest premiums, this shift increased inequality. Finally, we find some evidence that the increase in the size of the informal sector is related to increased foreign competition - sectors with larger tariff cuts and more trade exposure, as measured by the size their imports, saw a greater increase in informality, but only in the period prior to the labor market reform. Nevertheless, increasing returns to education, and changes in industry premiums and informality alone cannot fully explain the increase in wage inequality we observe over this period. This suggests that overall the effect of the trade reforms on the wage distribution may have been small.

Much work remains to be done. The two items that should be at the top of the research agenda in this area are the study of the flows into unemployment (as this is bound to be an important component of the adjustment mechanism, at least in the short run), and the effect that unemployment -- to the extent that it is not randomly distributed -- may have on measured wage inequality. Unfortunately, our current data is not well suited for answering this question. In addition, the difference between the Colombian and Mexican experience is interesting and worth further exploring, as it provides a fruitful ground for studying the conditions under which policies aimed at promoting growth and efficiency have no (or relatively small) adverse effects on the wage distribution. One potential explanation for the larger effect of the reforms on wage inequality in Mexico hinges on the role of foreign direct investment, which was large in Mexico (see Cragg and Epelbaum (1996) and Feenstra and Hanson (1997)). We do not attempt to resolve these issues in this paper, but we leave them as a topic for further research. Finally, the effect that competitive pressures may have on technology adoption and therefore on the demand for skills is, in our opinion, a particularly important question deserving further investigation. 


\section{References}

Acemoglu, D. (2002a): "Patterns of Skill Premia", forthcoming Review of Economic Studies .

Acemoglu, D. (2002b): “Technical Change, Inequality, and the Labor Market", Journal of Economic Literature, Vol. 40, pp.7-72 .

Attanasio, O. and M. Szekely (2000): "Household Saving in East Asia and Latin America: Inequality Demographics and All That", in: Annual World Bank Conference on Development Economics.

Bell, L. (1997): “The Impact of Minimum Wages in Mexico and Colombia”, Journal of Labor Economics, Vol. 15, pp. S103-135.

Berman, E., Machin, S., and Bound, J. (1998): Implications of skill-biased technological changes: International Evidence. Quarterly Journal of Economics 113, 1245-1279.

Cragg, M.I. and M. Epelbaum (1996): "Why has wage dispersion grown in Mexico? Is it the incidence of reforms or the growing demand for skills?", Journal of Development Economics, Vol. 51, pp. 99-116.

Currie, J. and A. Harrison (1997): “Trade Reform and Labor Market Adjustment in Morocco", Journal of Labor Economics, Vol. 15, pp. S44-71.

Dickens, W.T. and L.F. Katz (1986): "Interindustry Wage Differences and Industry Characteristics", NBER Working Paper No. 2014.

Echavarria, J., C. Gamboa and R. Guerrero (2000): "Escenarios de reforma a la estructura arancelaria de la comunidad Andina", Fedesarrollo, manuscript. 
Edwards, S. (2001): The economics and politics of transition to an open market economy: Colombia. OECD: Paris and Washington, D.C..

Feenstra, R. and G. Hanson (1997): "Foreign Direct Investment and Relative Wages: Evidence From Mexico’s Maquiladoras,” Journal of International Economics, 42(3-4), pp. 371-393.

Feliciano, Z. (2001): "Workers and Trade Liberalization: The impact of trade reforms in Mexico on wages and employment”, Industrial and Labor Relations Review, Vol. 55, No. 1.

Fernandes, A.M. (2001): “Trade Policy, Trade Volumes and Plant-Level Productivity in Colombian Manufacturing Industries", Yale University, manuscript.

Gaston, N. and D. Trefler (1994): "Protection, Trade and Wages: Evidence from U.S. Manufacturing”, Industrial and Labor Relations Review, Vol. 47, No. 4, pp. 574-593.

Goldberg, P. and N. Pavcnik (2003a): "Trade, Wages, and the Political Economy of Trade Protection: Evidence from the Colombian Trade Reforms", manuscript, January 2003. (2003b): "The Response of the Informal Sector to Trade Liberalization," Journal of Development Economics, forthcoming.

Grossman, G. (1984): “International Competition and the Unionized Sector", Canadian Journal of Economics, Vol. 17, No. 3, pp. 541-556.

Grossman, G. (1986): "Imports as a Cause of Injury: The Case of the U.S. Steel Industry", Journal of International Economics, 20(3-4), pp. 201-223.

Grossman, G. and E. Helpman (1994): "Protection for Sale", American Economic Review, Vol. 84(4), pp. 833-850. 
Haisken-DeNew, J.P. and C.M. Schmidt (1997): "Inter-Industry and Inter-Region Wage Differentials: Mechanics and Interpretation", Review of Economics and Statistics, Vol. 79, No. 3, pp. 516-521.

Hanson, G. and A. Harrison (1999): "Who gains from trade reform? Some remaining puzzles", Journal of Development Economics, Vol. 59, pp. 125-154.

Harrison, A. (1994): "Productivity, Imperfect Competition and Trade Reform: Theory and Evidence", Journal of International Economics, Vol. 36 (1-2), pp. 53-73.

Harrison, A. and E. Leamer (1997): "Labor markets in developing countries: An agenda for research", Journal of Labor Economics, Vol. 15, pp. S1-19.

Heckman J. and Pages C. (2000): “The Cost of Job Security Regulation: Evidence from Latin American Labor Market," NBER Working Paper 7773.

Johnston, L.N. (1996): "Trade Liberalization and Income Distribution: Insight from the Colombian Reform", Chapter 1 of Ph. D thesis: "Returns to Education, Human Capital and Income Inequality in Colombia", Harvard University.

Katz, L.F. and L. H. Summers (1989): "Industry Rents: Evidence and Implications", Brookings Papers on Economic Activity, Microeconomics, pp. 209-275.

Kim, E. (2000): "Trade Liberalization and Productivity Growth in Korean Manufacturing Industries: Price Protection, Market Power and Scale Efficiency", Journal of Development Economics, Vol. 62(1), pp. 55-83.

Krishna, P. and D. Mitra (1998): “Trade Liberalization, Market Discipline and Productivity Growth; New Evidence from India”, Journal of Development Economics, Vol. 56(2), pp. 447462. 
Krueger, A.B. and L.H. Summers (1987): "Reflections on the Inter-Industry Wage Structure", in Lang, K. and S. Leonard (eds.): Unemployment and the Structure of Labor Markets, Basil Blackwell, pp. 17-47.

Krueger, A.B. and L.H. Summers (1988): "Efficiency Wages and the Inter-Industry Wage Structure", Econometrica, Vol. 56, pp. 259-293.

Kugler, A. (1999): "The Impact of Firing Costs on Turnover and Unemployment: Evidence from The Colombian Labour Market Reform", International Tax and Public Finance Journal, Vol. 6, no. 3, pp. 389-410.

Leamer, E. (1994): “Trade, Wages and the Revolving Door Ideas”, NBER Working Paper, \#4716, 1994.

Leamer, E. (1996): “What's the use of factor contents?” NBER Working Paper \#5448, 1996.

Leamer, E. (1998): "In search of Stolper-Samuelson Effects on U.S. Wages," in S.Collins, ed., Exports, imports and the American economy, Brookings, 1998.

Leamer, E., H. Maul, S. Rodriguez, and P. Schott (2002): "Does Natural Resource Abundance Cause Latin American Inequality?" Journal of Development Economics, 59(1), pp. $3-42$.

Montenegro, S. and X. Pena (2000): "Labor reforms, macroeconomic imbalances, and unemployment in Colombia," manuscript, Los Andes University.

Nuñez Mendez, J. and F. Sanchez Torres (2001): “A Dynamic Analysis of Household Decision Making in Urban Colombia, 1976-1998”, manuscript, Bogota, Colombia.

Pavcnik. N. (2002): “Trade Liberalization, Exit and Productivity Improvements: Evidence from Chilean Plants ”, Review of Economic Studies, 69, January 2002, pp. 245-76. 
Pavcnik. N. (2003): "What explains skill upgrading in less developed countries?", Journal of Development Economics forthcoming.

Rodrik, D. (1991): “Closing the Productivity Gap: Does Trade Liberalization Really Help?”, in: Helleiner, G. (ed.) Trade Policy, Industrialization and Development, Clarendon Press, Oxford.

Revenga, A. (1992): "Exporting Jobs? The Impact of Import Competition on Employment and Wages in U.S. Manufacturing”, Quarterly Journal of Economics, 107(1), pp. 255-284.

Revenga, A. (1997): "Employment and wage effects of trade liberalization: The Case of Mexican Manufacturing”, Journal of Labor Economics, Vol. 15, pp. S20-43.

Robbins, D. (1996): "Evidence on Trade and Wages in the Developing World," OECD Technical Paper No. 119.

Roberts, M. and J. Tybout (1991): "Size Rationalization and Trade Exposure in Developing Countries", in Baldwin, R. (ed.) Empirical Studies of Commercial Policy, University of Chicago Press.

Roberts, M. and J. Tybout (eds.) (1996): Industrial Evolution in Developing Countries: Micro Patterns of Turnover, Productivity and Market Structure, Oxford University Press, New York.

Roberts, M. and J. Tybout (1997): "The Decision to Export in Colombia: An Empirical Model of Entry with Sunk Costs", American Economic Review, Vol. 87, pp. 545-564.

Robertson, R. (1999): “Inter-Industry Wage Differentials Across Time, Borders, and Trade Regimes: Evidence from the U.S. and Mexico”, Macalester College, manuscript. 
Stallings, B. and W. Peres (2000), "Growth, Employment and Equity. The Impact of the Economic Reforms in Latin American and Caribbean”, Economic Commission for Latin American and Caribbean, Brookings Institution Press, Washington.

Thoenig, M and T Verdier (2002): “A Theory of Defensive Skill-based Innovation and Globalization", forthcoming American Economic Review.

United Nations (1994): Directory of Import Regimes Part I: Monitoring Import Regimes, United Nations, Geneva.

Wood, A. (1995): “How Trade Hurt Unskilled Workers”, Journal of Economic Perspectives, $9(3)$, pp. 57-80.

Wood, A. (1999): “Openness and Wage Inequality in Developing Countries: The Latin American Challenge to East Asian Conventional Wisdom", in: Baldwin, R. et-al. (eds.) Market integration, regionalism and the global economy, Cambridge University Press, pp. 153-181. 
Figure 1-Tariff Reductions and Share of Unskilled Workers

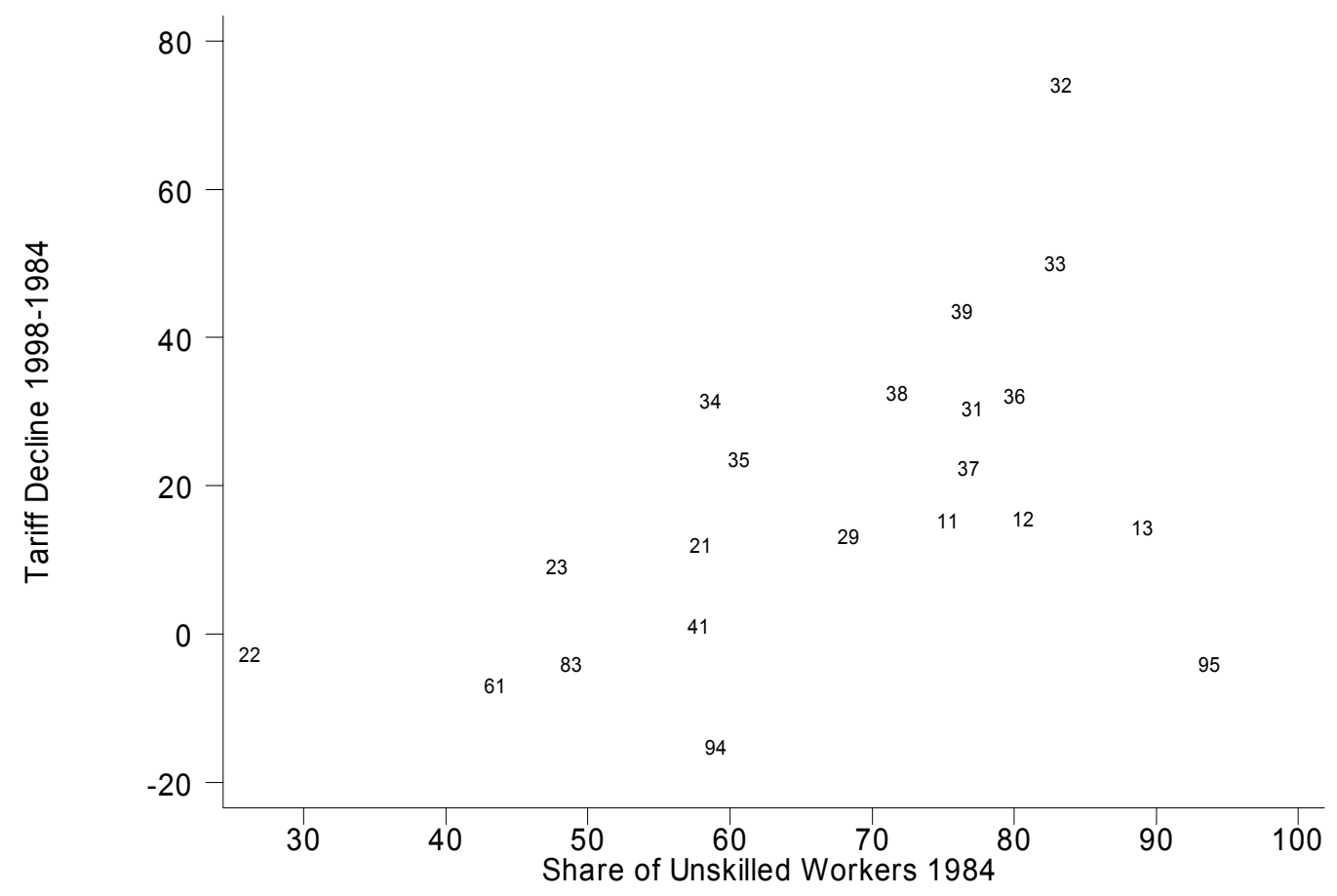

Figure 2-Tariff Reductions and Initial (1984) Wage Premiums

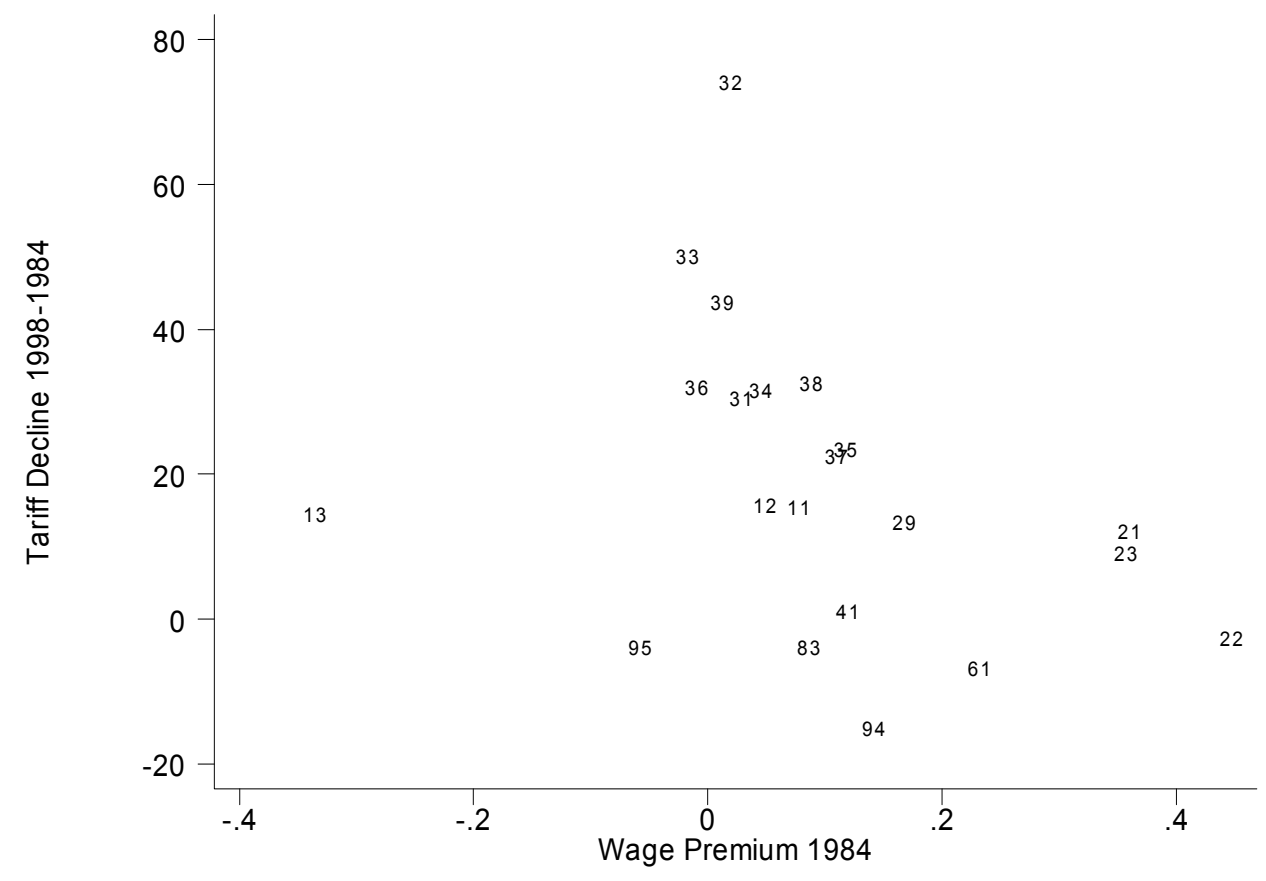


Table 1a--Trade Policy Summary

\begin{tabular}{cccccc}
\hline \hline Year & $\mathrm{N}$ & Mean & S.D. & Min & Max \\
$\begin{array}{lrrr}\text { Tariffs } \\
\text { All Industries }\end{array}$ & & & & & \\
1984 & 21 & 27.4 & 24.8 & 0.0 & 91.0 \\
1985 & 21 & 22.2 & 16.7 & 0.0 & 50.1 \\
1988 & 21 & 20.7 & 16.0 & 0.0 & 48.7 \\
1990 & 21 & 17.5 & 14.0 & 0.0 & 38.7 \\
1992 & 21 & 10.6 & 4.1 & 5.0 & 17.7 \\
1994 & 21 & 9.7 & 4.8 & 0.0 & 17.8 \\
1996 & 21 & 9.8 & 5.1 & 0.0 & 17.9 \\
1998 & 21 & 9.9 & 5.1 & 0.0 & 17.9
\end{tabular}

Manufacturing

$\begin{array}{lrrrrr}1984 & 9 & 49.8 & 19.0 & 29.2 & 91.0 \\ 1985 & 9 & 36.6 & 9.5 & 22.5 & 50.1 \\ 1988 & 9 & 33.5 & 11.1 & 17.1 & 48.7 \\ 1990 & 9 & 29.1 & 9.1 & 15.2 & 38.7 \\ 1992 & 9 & 12.9 & 3.4 & 8.4 & 17.7 \\ 1994 & 9 & 12.9 & 3.6 & 8.0 & 17.8 \\ 1996 & 9 & 13.0 & 3.9 & 7.5 & 17.9 \\ 1998 & 9 & 13.1 & 3.8 & 7.8 & 17.9\end{array}$

$\underline{\text { NTBs }}$

All Industries

\begin{tabular}{rrrrrr}
1986 & 17 & 72.4 & 15.3 & 38.5 & 89.5 \\
1988 & 17 & 72.9 & 16.1 & 37.7 & 93.7 \\
1992 & 17 & 1.1 & 1.2 & 0.0 & 4.5 \\
\hline
\end{tabular}

Note: $\mathrm{N}$ stands for number of 2-digit ISIC industries with available data. Authors' calculations based on tariff and NTB data provided by DNP and the UN. 
Table 1b--National Household Survey Summary Statistics

\begin{tabular}{|c|c|c|c|c|c|c|c|c|}
\hline & 1984 & 1986 & 1988 & 1990 & 1992 & 1994 & 1996 & 1998 \\
\hline Hourly wage (current pesos) & 115.4 & 168.7 & 259.1 & 430.5 & 686.9 & 1337.6 & 1850.6 & 2725.0 \\
\hline log hourly wage & 4.4 & 4.8 & 5.2 & 5.7 & 6.1 & 6.7 & 7.0 & 7.4 \\
\hline Weekly wage (current pesos) & 5109.0 & 7158.4 & 11396.0 & 18787.2 & 30000.1 & 59260.2 & 79884.4 & 112281.7 \\
\hline log weekly wage & 8.2 & 8.5 & 9.0 & 9.5 & 9.9 & 10.5 & 10.8 & 11.2 \\
\hline Male & .622 & .619 & .601 & .606 & .587 & .591 & .589 & .553 \\
\hline Age & 33.7 & 33.8 & 33.9 & 34.3 & 34.3 & 34.7 & 35.2 & 35.6 \\
\hline Married & .427 & .413 & .385 & .411 & .392 & .357 & .358 & .356 \\
\hline Head of the household & .471 & .468 & .453 & .474 & .459 & .462 & .464 & .457 \\
\hline Literate & .970 & .973 & .978 & .980 & .978 & .985 & .982 & .981 \\
\hline No complete schooling & .218 & .197 & .178 & .155 & .144 & .121 & .118 & .119 \\
\hline Elementary school complete & .489 & .479 & .480 & .479 & .473 & .465 & .434 & .393 \\
\hline Secondary school complete & .218 & .238 & .250 & .264 & .282 & .304 & .326 & .350 \\
\hline University complete* & .076 & .087 & .092 & .102 & .101 & .109 & .121 & .137 \\
\hline Lives in Bogota & .434 & .435 & .424 & .429 & .402 & .524 & .439 & .386 \\
\hline \multicolumn{9}{|l|}{ Occupation Indicators } \\
\hline Professional/Technical & .103 & .103 & .107 & .109 & .113 & .111 & .121 & .135 \\
\hline Management & .012 & .013 & .013 & .018 & .020 & .020 & .016 & .021 \\
\hline Personnel & .138 & .133 & .128 & .126 & .124 & .137 & .130 & .132 \\
\hline Sales & .180 & .186 & .195 & .192 & .190 & .191 & .201 & .196 \\
\hline Servant & .194 & .196 & .188 & .185 & .191 & .172 & .174 & .194 \\
\hline Agricultural/Forest & .013 & .013 & .015 & .016 & .013 & .009 & .010 & .010 \\
\hline Manual Manufacturing & .360 & .356 & .354 & .353 & .348 & .360 & .347 & .312 \\
\hline \multicolumn{9}{|l|}{ Job Type Indicators } \\
\hline Private Employee & .530 & .550 & .551 & .546 & .564 & .585 & .569 & .523 \\
\hline Government Employee & .118 & .116 & .107 & .108 & .099 & .080 & .085 & .089 \\
\hline Private Household Employee & .064 & .067 & .058 & .054 & .050 & .035 & .032 & .047 \\
\hline Self-employed & .242 & .220 & .227 & .227 & .224 & .234 & .261 & .282 \\
\hline Employer & .046 & .047 & .056 & .065 & .064 & .066 & .053 & .059 \\
\hline \multicolumn{9}{|l|}{ Place of work characteristics } \\
\hline single-person establishment & & .250 & .244 & .253 & .247 & .252 & .263 & .311 \\
\hline 2 to 5 person establishment & & .218 & .223 & .192 & .215 & .193 & .205 & .196 \\
\hline 6-10 person establishment & & .080 & .093 & .063 & .083 & .085 & .078 & .073 \\
\hline 11 or more person establishment & & .451 & .440 & .492 & .455 & .470 & .454 & .420 \\
\hline Work in a building & & .597 & .600 & .674 & .608 & .615 & .616 & .597 \\
\hline Informal sector & & .577 & .568 & .574 & .564 & .516 & .609 & .590 \\
\hline Number of observations & 36,717 & 28,481 & 31,006 & 25,950 & 27,521 & 18,070 & 27,365 & 30,092 \\
\hline
\end{tabular}

Note: The reported means are weighted using survey weights. We define complete university if a person completes 5 or more years of post secondary education. 
Table 2a--Aggregate Wage Inequality

\begin{tabular}{crrr}
\hline \hline Year & Std. Log Wage & & $90-10$ Percentile \\
84 & & \\
86 & .809 & 1.881 \\
88 & .816 & 1.938 \\
90 & .793 & 1.841 \\
92 & .773 & 1.833 \\
94 & .812 & 1.938 \\
96 & .816 & 1.857 \\
98 & .820 & 1.897 \\
\hline \hline
\end{tabular}


Table 2b--Wage Inequality Within Education Categories

\begin{tabular}{|c|c|c|c|c|c|c|}
\hline & \multicolumn{3}{|c|}{ Std. Of Log Wage } & \multicolumn{3}{|c|}{ 90-10 Percentile } \\
\hline & $\begin{array}{l}\text { no school/ } \\
\text { elementary }\end{array}$ & secondary & university & $\begin{array}{l}\text { no school/ } \\
\text { elementary }\end{array}$ & secondary & university \\
\hline 84 & .722 & .652 & .673 & 1.650 & 1.519 & 1.611 \\
\hline 86 & .742 & .670 & .706 & 1.695 & 1.504 & 1.747 \\
\hline 88 & .696 & .690 & .734 & 1.609 & 1.455 & 1.792 \\
\hline 90 & .675 & .656 & .702 & 1.540 & 1.447 & 1.828 \\
\hline 92 & .717 & .687 & .695 & 1.649 & 1.553 & 1.757 \\
\hline 94 & 680 & .718 & .845 & 1.482 & 1.571 & 1.920 \\
\hline 96 & .694 & 699 & .789 & 1.584 & 1.558 & 1.879 \\
\hline 98 & .754 & .742 & .798 & 1.735 & 1.658 & 1.897 \\
\hline
\end{tabular}


Table 3--Estimates of Earnings Equation

\begin{tabular}{|c|c|c|c|c|c|c|c|}
\hline & 1986 & 1988 & 1990 & 1992 & 1994 & 1996 & $\overline{\overline{1998}}$ \\
\hline \multirow[t]{2}{*}{ age } & .033 & .030 & .028 & .032 & .022 & .026 & .030 \\
\hline & {$[0.002]$} & {$[0.002]$} & [0.002] & {$[0.002]$} & {$[0.002]$} & {$[0.002]$} & {$[0.002]$} \\
\hline \multirow[t]{2}{*}{ age squared } & -.0003 & -.0003 & -.0003 & -.0003 & -.0002 & -.0002 & -.0003 \\
\hline & {$[0.0000]$} & {$[0.0000]$} & {$[0.0000]$} & {$[0.0000]$} & {$[0.0000]$} & {$[0.0000]$} & {$[0.0000]$} \\
\hline \multirow[t]{2}{*}{ male } & .119 & .142 & 107 & .124 & .059 & .077 & .085 \\
\hline & {$[0.010]$} & [0.009] & {$[0.010]$} & {$[0.010]$} & {$[0.013]$} & {$[0.010]$} & {$[0.010]$} \\
\hline \multirow[t]{2}{*}{ married } & .102 & .098 & .076 & .076 & .078 & .083 & .092 \\
\hline & {$[0.009]$} & {$[0.008]$} & {$[0.009]$} & {$[0.009]$} & {$[0.011]$} & {$[0.009]$} & {$[0.009]$} \\
\hline \multirow[t]{2}{*}{ head of the household } & .065 & .076 & .081 & .068 & .098 & .095 & .082 \\
\hline & {$[0.010]$} & [0.009] & {$[0.010]$} & {$[0.010]$} & {$[0.012]$} & {$[0.010]$} & {$[0.010]$} \\
\hline \multirow[t]{2}{*}{ elementy school } & .225 & 194 & .165 & 219 & .210 & 191 & 189 \\
\hline & {$[0.011]$} & {$[0.010]$} & {$[0.011]$} & {$[0.012]$} & {$[0.016]$} & {$[0.013]$} & {$[0.013]$} \\
\hline \multirow[t]{2}{*}{ secondary school } & .512 & .456 & .428 & .483 & .490 & .448 & .474 \\
\hline & {$[0.014]$} & {$[0.013]$} & {$[0.014]$} & {$[0.015]$} & {$[0.019]$} & {$[0.015]$} & {$[0.015]$} \\
\hline \multirow[t]{2}{*}{ university degree } & .878 & .849 & .784 & .877 & .955 & .921 & .984 \\
\hline & {$[0.023]$} & {$[0.020]$} & {$[0.021]$} & {$[0.022]$} & {$[0.027]$} & {$[0.022]$} & {$[0.022]$} \\
\hline \multirow{2}{*}{ literate } & .190 & .229 & .183 & .186 & .115 & .152 & .157 \\
\hline & {$[0.023]$} & {$[0.023]$} & {$[0.026]$} & {$[0.026]$} & {$[0.038]$} & [0.029] & {$[0.028]$} \\
\hline \multirow[t]{2}{*}{ lives in bogota } & .128 & .112 & 130 & .087 & .071 & .177 & 241 \\
\hline & {$[0.009]$} & {$[0.008]$} & [0.009] & {$[0.009]$} & {$[0.010]$} & {$[0.010]$} & [0.013] \\
\hline \multirow{2}{*}{ Professional } & .397 & .457 & .476 & . 479 & 477 & .480 & .459 \\
\hline & {$[0.022]$} & {$[0.020]$} & {$[0.020]$} & {$[0.020]$} & [0.027] & {$[0.021]$} & {$[0.021]$} \\
\hline \multirow[t]{2}{*}{ Management } & .600 & .742 & .836 & .935 & .701 & .671 & 613 \\
\hline & {$[0.040]$} & {$[0.038]$} & {$[0.035]$} & {$[0.035]$} & {$[0.040]$} & {$[0.036]$} & {$[0.037]$} \\
\hline \multirow[t]{2}{*}{ Personell } & .127 & .120 & .111 & .143 & .141 & .144 & .097 \\
\hline & [0.018] & [0.016] & [0.017] & [0.017] & [0.022] & [0.017] & [0.018] \\
\hline \multirow[t]{2}{*}{ Sales } & .155 & .156 & 147 & 191 & 218 & 198 & 149 \\
\hline & [0.019] & {$[0.018]$} & {$[0.018]$} & {$[0.018]$} & [0.023] & {$[0.018]$} & [0.019] \\
\hline \multirow[t]{2}{*}{ Blue collar worker Agriculture } & 117 & .210 & .156 & .153 & .257 & .116 & .143 \\
\hline & {$[0.050]$} & [0.046] & [0.049] & [0.049] & {$[0.065]$} & {$[0.056]$} & {$[0.051]$} \\
\hline Blue collar worker Manufacturing & .075 & .092 & .071 & .104 & .100 & .110 & .032 \\
\hline & {$[0.016]$} & [0.015] & [0.015] & {$[0.015]$} & {$[0.020]$} & {$[0.016]$} & {$[0.016]$} \\
\hline private firm employee & -.468 & -.499 & -.478 & -.433 & -.525 & -.433 & -.425 \\
\hline & {$[0.020]$} & [0.017] & {$[0.018]$} & {$[0.018]$} & {$[0.023]$} & [0.019] & [0.019] \\
\hline government employee & -.379 & -.401 & -.356 & -.327 & -.368 & -.312 & -.264 \\
\hline & [0.027] & [0.025] & [0.025] & {$[0.026]$} & {$[0.035]$} & {$[0.028]$} & [0.028] \\
\hline private $\mathrm{HH}$ employee & -.298 & -.223 & -.341 & -.224 & -.317 & -.084 & -.213 \\
\hline & [0.032] & [0.029] & [0.032] & [0.031] & [0.044] & [0.034] & {$[0.032]$} \\
\hline self-employed & -.527 & -.496 & -.394 & -.402 & -.459 & -.336 & -.498 \\
\hline & [0.024] & {$[0.021]$} & [0.024] & [0.024] & {$[0.031]$} & [0.024] & [0.023] \\
\hline born in urban area & .053 & .051 & .079 & .070 & .043 & .058 & .076 \\
\hline & {$[0.020]$} & [0.019] & [0.020] & [0.022] & [0.028] & [0.022] & {$[0.025]$} \\
\hline time in residence & .000 & -.001 & -.001 & -.002 & -.002 & -.003 & -.001 \\
\hline & [0.001] & [0.001] & [0.001] & [0.001] & [0.001] & [0.001] & [0.001] \\
\hline urban birth*time in residence & .001 & .002 & .001 & .002 & .002 & .002 & .000 \\
\hline & {$[0.001]$} & [0.001] & [0.001] & {$[0.001]$} & {$[0.001]$} & [0.001] & {$[0.001]$} \\
\hline informal sector & -.045 & -.056 & -.058 & -.036 & -.017 & -.131 & -.116 \\
\hline & {$[0.011]$} & {$[0.010]$} & [0.009] & {$[0.010]$} & [0.013] & {$[0.010]$} & {$[0.011]$} \\
\hline establishment with 2-5 people & -.015 & -.016 & .011 & .025 & -.035 & .070 & .016 \\
\hline & {$[0.017]$} & {$[0.015]$} & [0.019] & [0.019] & [0.026] & [0.018] & {$[0.017]$} \\
\hline establishment with $6-10$ people & .044 & .096 & 128 & .124 & .043 & .139 & .088 \\
\hline & {$[0.022]$} & {$[0.020]$} & [0.025] & [0.023] & {$[0.031]$} & [0.023] & {$[0.022]$} \\
\hline establishment with 11 or more $p$. & .117 & .129 & .169 & 190 & .088 & .181 & .130 \\
\hline & {$[0.020]$} & [0.019] & [0.022] & [0.022] & [0.028] & {$[0.020]$} & [0.019] \\
\hline works in a building & .150 & .176 & 134 & .117 & .156 & .138 & .113 \\
\hline & [0.011] & {$[0.010]$} & [0.011] & [0.011] & [0.014] & [0.011] & [0.011] \\
\hline Number of Observations & 28481 & 31006 & 25950 & 27521 & 18070 & 27365 & 30092 \\
\hline R2 & .37 & .40 & .41 & .40 & .37 & .39 & 41 \\
\hline Industry Indicators & yes & yes & yes & yes & yes & yes & yes \\
\hline
\end{tabular}




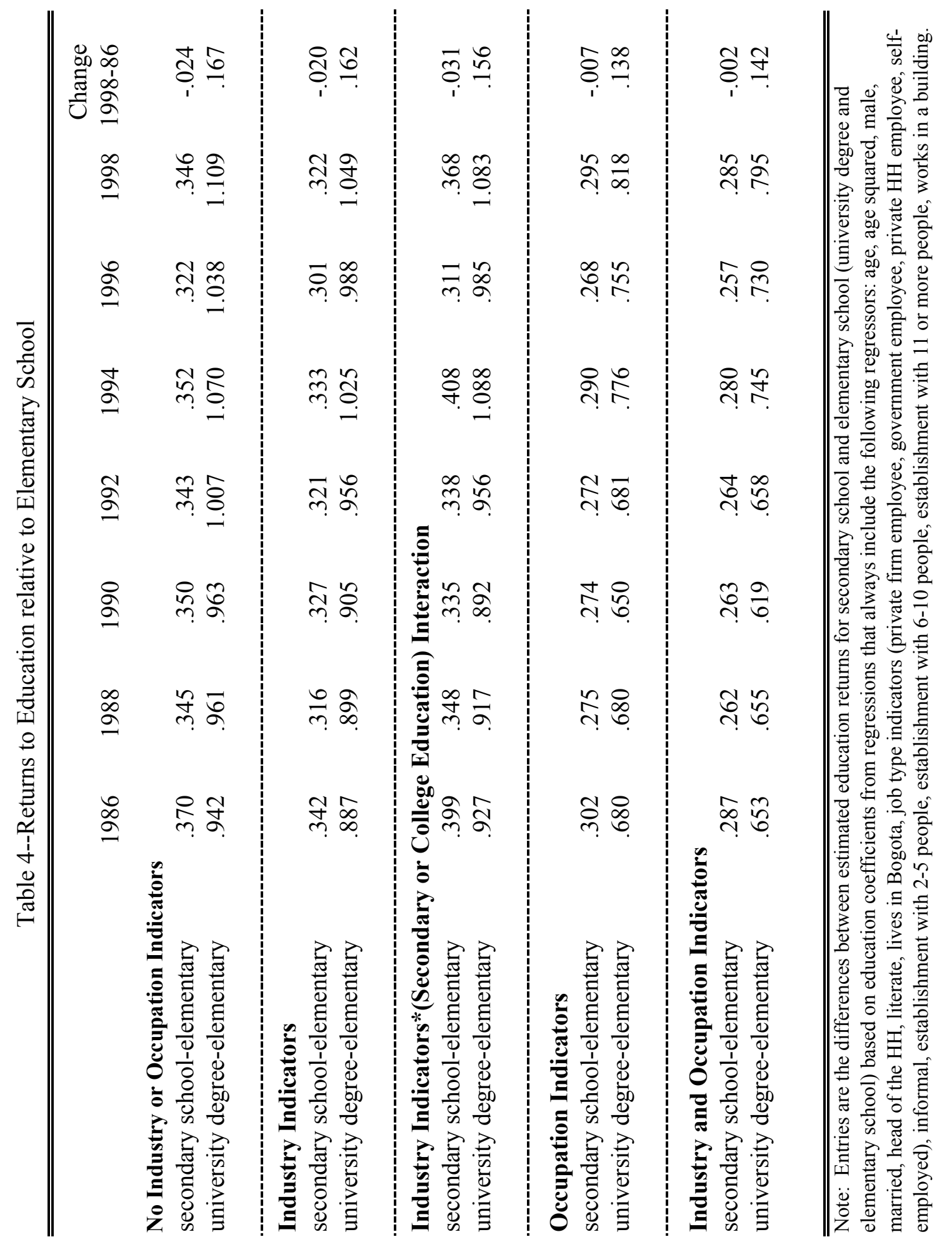


Table 5--Industry Employment

\begin{tabular}{|c|c|c|c|c|}
\hline \multirow[t]{2}{*}{ ISIC Code } & \multicolumn{2}{|c|}{$\begin{array}{c}\text { Industry Share in Overall } \\
\text { Employment }\end{array}$} & \multicolumn{2}{|c|}{$\begin{array}{c}\text { Share of Skilled Workers in } \\
\text { Industry }\end{array}$} \\
\hline & 1984 & 1998 & 1984 & 1998 \\
\hline 11 & .0130 & .0091 & .247 & .289 \\
\hline 12 & .0001 & .0001 & .194 & .272 \\
\hline 13 & .0003 & .0006 & .110 & .481 \\
\hline 21 & .0015 & .0005 & .421 & .537 \\
\hline 22 & .0015 & .0017 & .738 & .899 \\
\hline 23 & .0002 & .0001 & .522 & .371 \\
\hline 29 & .0005 & .0005 & .317 & .380 \\
\hline 31 & .0358 & .0343 & .230 & .498 \\
\hline 32 & .0908 & .0763 & .167 & .336 \\
\hline 33 & .0194 & .0166 & .171 & .321 \\
\hline 34 & .0158 & .0120 & .414 & .603 \\
\hline 35 & .0241 & .0211 & .394 & .621 \\
\hline 36 & .0107 & .0097 & .200 & .490 \\
\hline 37 & .0034 & .0031 & .232 & .389 \\
\hline 38 & .0348 & .0280 & .283 & .471 \\
\hline 39 & .0063 & .0053 & .237 & .505 \\
\hline 41 & .0049 & .0047 & .422 & .665 \\
\hline 42 & .0028 & .0016 & .295 & .701 \\
\hline 50 & .0691 & .0570 & .141 & .267 \\
\hline 61 & .0108 & .0155 & .565 & .625 \\
\hline 62 & .1932 & .1955 & .249 & .456 \\
\hline 63 & .0354 & .0406 & .133 & .278 \\
\hline 71 & .0560 & .0624 & .233 & .416 \\
\hline 72 & .0054 & .0109 & .502 & .830 \\
\hline 81 & .0219 & .0202 & .776 & .947 \\
\hline 82 & .0058 & .0057 & .752 & .918 \\
\hline 83 & .0436 & .0564 & .512 & .685 \\
\hline 91 & .0425 & .0369 & .545 & .851 \\
\hline 92 & .0017 & .0015 & .328 & .502 \\
\hline 93 & .0883 & .1078 & .705 & .857 \\
\hline 94 & .0132 & .0175 & .410 & .626 \\
\hline 95 & .1469 & .1461 & .063 & .194 \\
\hline 96 & .0003 & .0005 & .555 & .953 \\
\hline
\end{tabular}

Note: Skilled workers are workers with complete secondary or university education. 


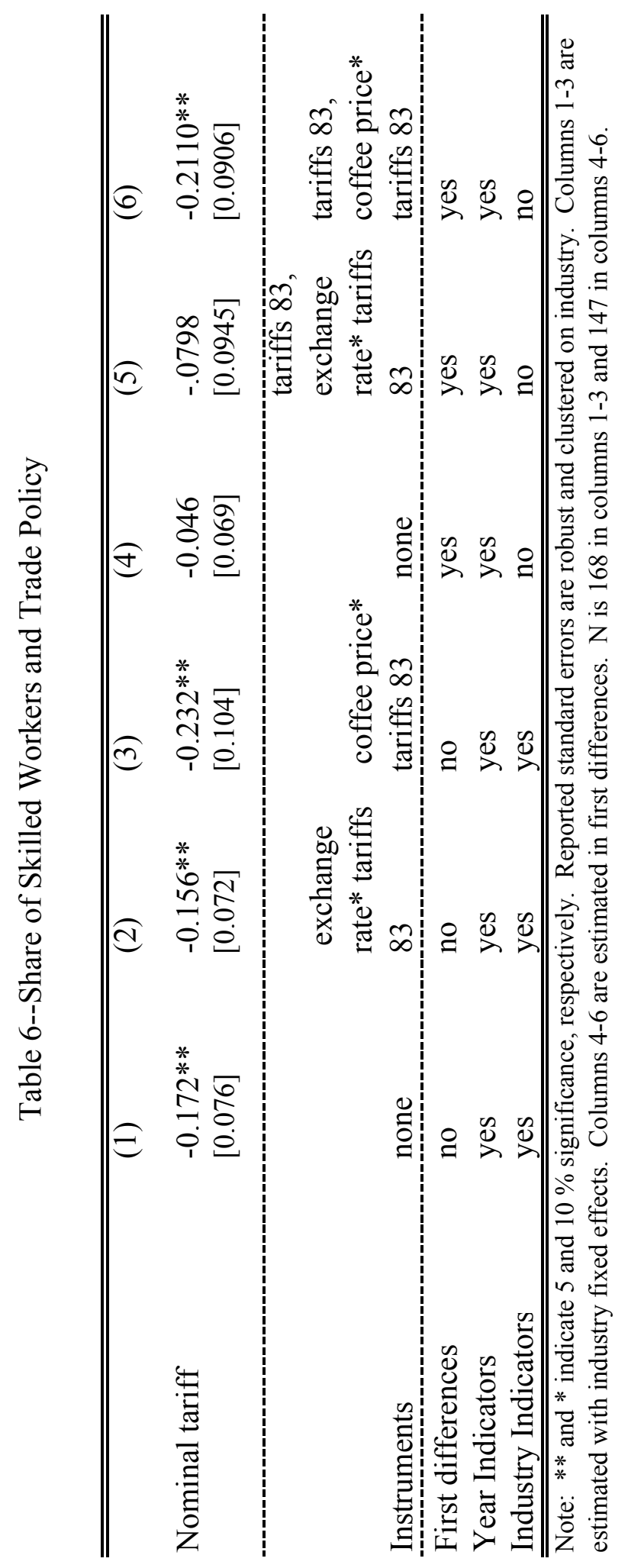




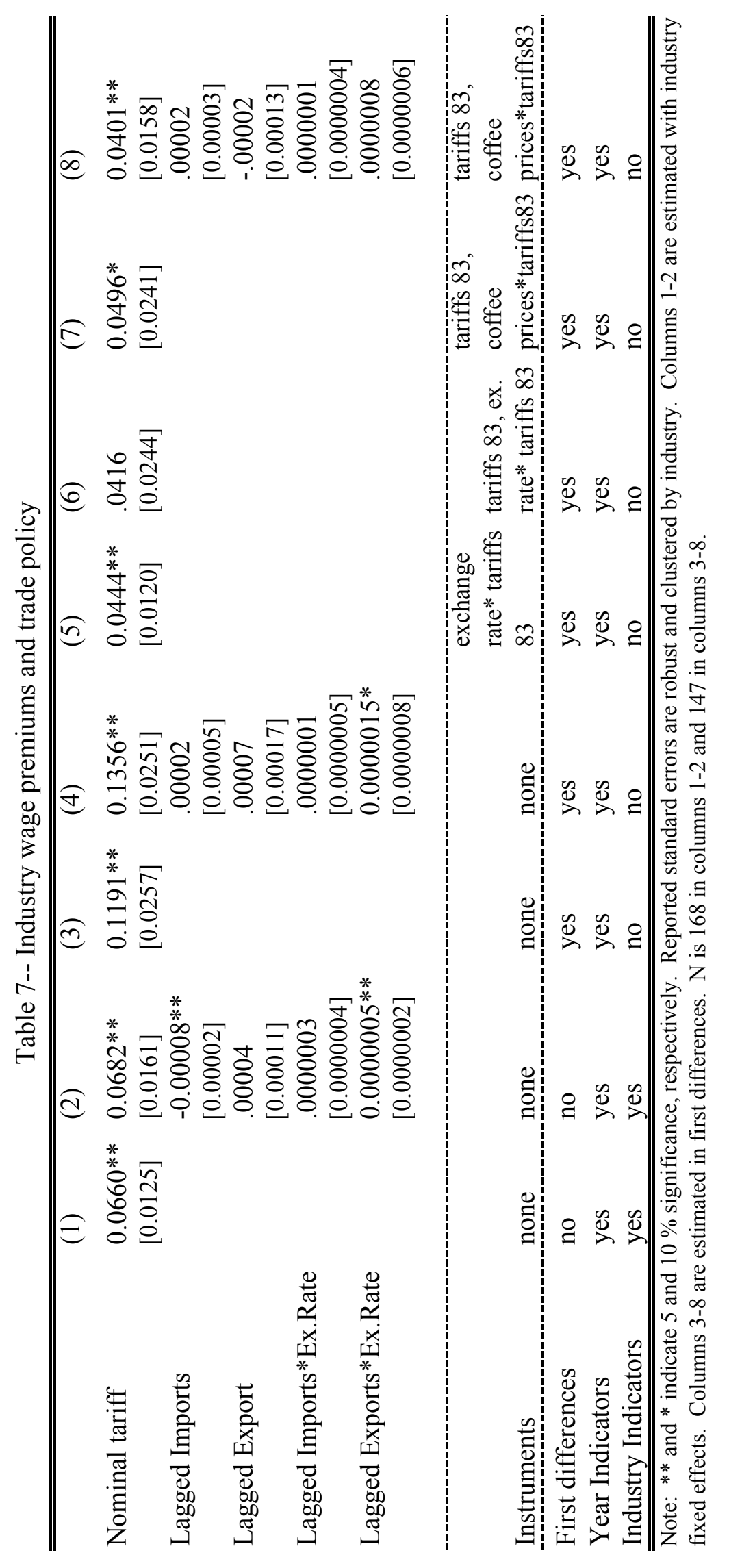




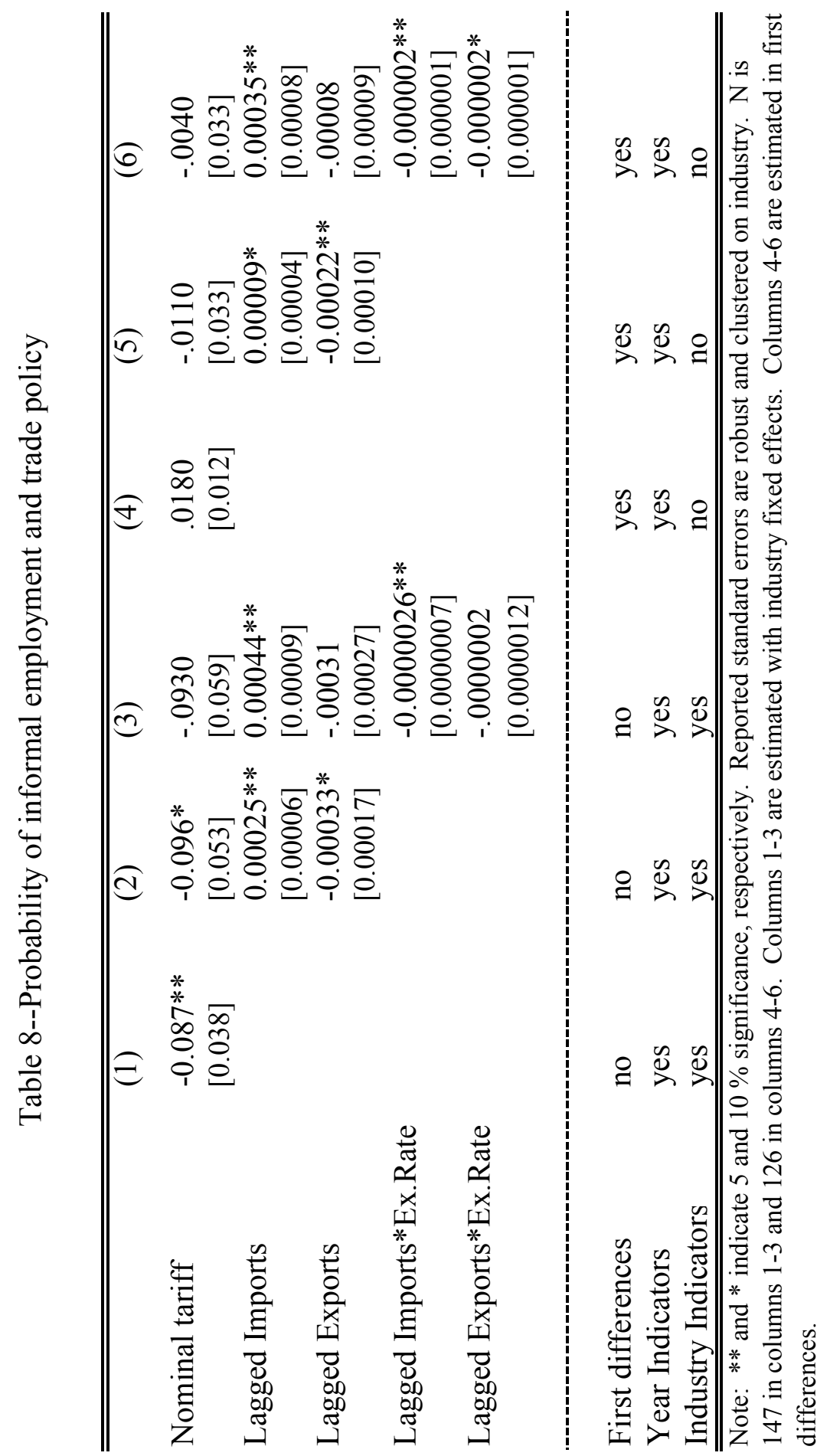


Table 9--Aggregate Unemployment

\begin{tabular}{cr}
\hline \hline Year & Unemployment \\
\hline 84 & .1369 \\
86 & .1459 \\
88 & .1193 \\
90 & .1097 \\
92 & .1113 \\
94 & .0974 \\
96 & .1175 \\
98 & .1584 \\
\hline \hline
\end{tabular}

Note: Share of unemployed in total labor force based on June waves of NHS. 
Table 10--Probability of Unemployment

\begin{tabular}{|c|c|c|}
\hline & (1) & (3) \\
\hline agriculture, hunting, forestry (ISIC 1 ) & $\begin{array}{l}0.059 * * \\
{[0.012]}\end{array}$ & $\begin{array}{l}0.026^{* *} \\
{[0.011]}\end{array}$ \\
\hline mining/quarrying (ISIC 2) & $\begin{array}{l}0.087^{* *} \\
{[0.028]}\end{array}$ & $\begin{array}{l}.026 \\
{[0.022]}\end{array}$ \\
\hline manufacturing (ISIC 3) & $\begin{array}{l}-.006 \\
{[0.004]}\end{array}$ & $\begin{array}{l}-0.009^{*} \\
{[0.004]}\end{array}$ \\
\hline electricity/gas/water (ISIC 4) & $\begin{array}{l}0.029^{*} \\
{[0.017]}\end{array}$ & $\begin{array}{l}-.005 \\
{[0.016]}\end{array}$ \\
\hline construction (ISIC 5) & $\begin{array}{l}0.097 * * \\
{[0.007]}\end{array}$ & $\begin{array}{l}0.046 * * \\
{[0.008]}\end{array}$ \\
\hline transportation/communication (ISIC 7) & $\begin{array}{l}0.016^{* *} \\
{[0.006]}\end{array}$ & $\begin{array}{l}.008 \\
{[0.006]}\end{array}$ \\
\hline Financing/insurance/business services (ISIC 8) & $\begin{array}{l}0.036^{* *} \\
{[0.007]}\end{array}$ & $\begin{array}{l}0.046^{* *} \\
{[0.008]}\end{array}$ \\
\hline Community/Social/Personal Services (ISIC 9) & $\begin{array}{l}-0.044 * * \\
{[0.004]}\end{array}$ & $\begin{array}{l}-0.031^{* *} \\
{[0.004]}\end{array}$ \\
\hline ISIC_ 1 *post trade reform year & $\begin{array}{l}-.014 \\
{[0.019]}\end{array}$ & $\begin{array}{l}-.003 \\
{[0.017]}\end{array}$ \\
\hline ISIC_2*post trade reform year & $\begin{array}{l}-.041 \\
{[0.041]}\end{array}$ & $\begin{array}{l}.047 \\
{[0.037]}\end{array}$ \\
\hline ISIC_ $3 *$ post trade reform year & $\begin{array}{l}-.008 \\
{[0.007]}\end{array}$ & $\begin{array}{l}-0.018^{* *} \\
{[0.006]}\end{array}$ \\
\hline ISIC_4*post trade reform year & $\begin{array}{l}-.035 \\
{[0.025]}\end{array}$ & $\begin{array}{l}.014 \\
{[0.023]}\end{array}$ \\
\hline ISIC_ $5 *$ post trade reform year & $\begin{array}{l}-.016 \\
{[0.011]}\end{array}$ & $\begin{array}{l}-.001 \\
{[0.011]}\end{array}$ \\
\hline ISIC_ $7 *$ post trade reform year & $\begin{array}{l}-0.033^{* *} \\
{[0.009]}\end{array}$ & $\begin{array}{l}-.010 \\
{[0.009]}\end{array}$ \\
\hline ISIC_ $8 *$ post trade reform year & $\begin{array}{l}-.010 \\
{[0.010]}\end{array}$ & $\begin{array}{l}-0.028^{* *} \\
{[0.011]}\end{array}$ \\
\hline ISIC_9*post trade reform year & $\begin{array}{l}.005 \\
{[0.006]}\end{array}$ & $\begin{array}{l}-.006 \\
{[0.006]}\end{array}$ \\
\hline post trade reform year & $\begin{array}{l}0.026^{* *} \\
{[0.004]}\end{array}$ & $\begin{array}{l}.005 \\
{[0.004]}\end{array}$ \\
\hline age & $\begin{array}{l}-0.015^{* *} \\
{[0.000]}\end{array}$ & $\begin{array}{l}-0.012^{* *} \\
{[0.000]}\end{array}$ \\
\hline agesq & $\begin{array}{l}0.000^{* *} \\
{[0.000]}\end{array}$ & $\begin{array}{l}0.000^{* *} \\
{[0.000]}\end{array}$ \\
\hline male & $\begin{array}{l}-0.042 * * \\
{[0.003]}\end{array}$ & $\begin{array}{l}-0.043 * * \\
{[0.003]}\end{array}$ \\
\hline married & $\begin{array}{l}-0.032 * * \\
{[0.002]}\end{array}$ & $\begin{array}{l}-0.017 * * \\
{[0.002]}\end{array}$ \\
\hline head of the $\mathrm{HH}$ & $\begin{array}{l}-0.075^{* *} \\
{[0.003]}\end{array}$ & $\begin{array}{l}-0.064 * * \\
{[0.003]}\end{array}$ \\
\hline elementy school & $\begin{array}{l}0.015^{* *} * \\
{[0.003]}\end{array}$ & $\begin{array}{l}0.009 * * \\
{[0.003]}\end{array}$ \\
\hline secondary school & $\begin{array}{l}0.009 * * \\
{[0.004]}\end{array}$ & $\begin{array}{l}.005 \\
{[0.004]}\end{array}$ \\
\hline university degree & $\begin{array}{l}-0.035^{* *} \\
{[0.004]}\end{array}$ & $\begin{array}{l}-0.037 * * \\
{[0.004]}\end{array}$ \\
\hline literate & $\begin{array}{l}0.011^{*} \\
{[0.007]}\end{array}$ & $\begin{array}{l}0.016^{* *} \\
{[0.006]}\end{array}$ \\
\hline lives in bogota & $\begin{array}{l}-0.022 * * \\
{[0.003]}\end{array}$ & $\begin{array}{l}-0.023 * * \\
{[0.003]}\end{array}$ \\
\hline born in urban area & $\begin{array}{l}0.027 * * \\
{[0.006]}\end{array}$ & $\begin{array}{l}0.023 * * \\
{[0.006]}\end{array}$ \\
\hline time in residence & $\begin{array}{l}0.001 * * \\
{[0.000]}\end{array}$ & $\begin{array}{l}0.001 * * \\
{[0.000]}\end{array}$ \\
\hline urban birth*time in residence & $\begin{array}{l}-0.001 * * \\
{[0.000]}\end{array}$ & $\begin{array}{l}-0.001^{* *} \\
{[0.000]}\end{array}$ \\
\hline Years Used & 1984,1998 & 1988,1992 \\
\hline Post Trade Reform year & 1998 & 1992 \\
\hline Number of Observations & 91393 & 79807 \\
\hline
\end{tabular}

